\title{
The Upper Part of the Upper
}

Triassic Chinle Formation

and Related Rocks,

Southeastern Utah and

Adjacent Areas

By ROBERT B. O'SULLIVAN

SHORTER CONTRIBUTIONS TO GENERAL GEOLOGY

GEOLOGICAL SURVEY PROFESIONAL PAPER 644-E

Prepared in cooperation with the Bureau of

Indian Affairs and the Navajo Tribe

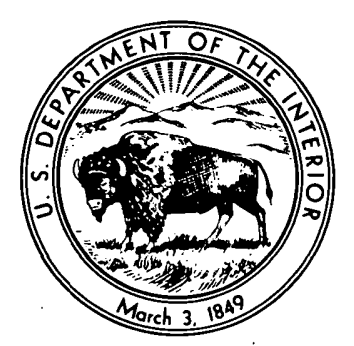

UNITED STATES GOVERNMENT PRINTING OFFICE, WASHINGTON : 1970 


\section{UNITED STATES DEPARTMENT OF THE INTERIOR}

WALTER J. HICKEL, Secretary

\section{GEOLOGICAL SURVEY}

William T. Pécora, Director 


\section{CONTENTS}

Abstract.

Introduction _.

Stratigraphy _.

Stratigraphic relations in southern Monument Valley

Stratigraphic relations in northeastern Monument Valley

Owl Rock Member.-.

Reddish-orange siltstone member $\ldots \ldots \ldots \ldots$

Mule Ear ledge.

Hite Bed.-.-

Unconformity at the base of the Hite Bed

Division A_.

Stratigraphic relations in northwestern Monument Valley

Regional relations.

Grain size._.

Clay minerals.

Fossils_._.

Chinle Formation-Glen Canyon Group contact.

Paleogeography

Conclusions_._.

References cited

\section{ILLUSTRATIONS}

FIGURE 1. Map of northeast Arizona and adjacent areas.....

2. Nomenclature of Chinle Formation and related rocks of Gregory (1917)

3. Graphic sections and stratigraphic diagram showing correlation of upper part of Chinle Formation and related rocks along Comb Ridge.

4. Photograph of Upper Triassic rocks along Comb Ridge...

5. Photograph of west wall of Comb Ridge

6. Generalized diagram showing stratigraphic relations of Chinle Formation and related rocks

7. Generalized fence diagram of Chinle Formation and related rocks.

8. Paleogeographic map of northeast Arizona and adjacent areas 


\title{
THE UPPER PART OF THE UPPER TRIASSIC CHINLE FORMATION AND RELATED ROCKS, SOUTHEASTERN UTAH AND ADJACENT AREAS
}

\author{
By Robert B. O'Sullivan
}

\begin{abstract}
In northeastern Arizona the Owl Rock Member of the Chinle Formation is overlain by a unit of reddish-orange very fine grained sandstone and siltstone. Previously, this reddish-orange unit has been referred to informally as division $A$ of the Chinle Formation. Division A is recognized throughout northeastern Arizona; stratigraphic studies show that the unit extends not more than 8 miles into southeastern Utah. In different parts of northeastern Arizona, division A is named the Rock Point Member of the Wingate Sandstone or the Church Rock Member of the Chinle Formation. In southeastern Utah and parts of northeastern Arizona a fluviatile sandstone-the Hite Bed-is at the top of the Chinle Formation, and stratigraphic studies show it to be equivalent to division $A$. In much of southeastern Utah a unit of reddish-orange very fine grained sandstone and siltstone is present below the Hite Bed and is also called Church Rock Member of the Chinle Formation. However, the stratigraphic relations, grain-size analyses, clay minerals, and fossil content show that it is a separate unit equivalent to the Owl Rock Member of the Chinle Formation. It is the author's opinion that rocks formerly assigned to division $A$ of the Chinle Formation be everywhere called the Rock Point Member of the Wingate Sandstone and that the so-called Church Rock of southeastern Utah be renamed.

A widespread unconformity that separates the Chinle Formation, as here defined, from overlying rocks extends from southern Nevada across southwestern Utah and northeastern Arizona to northwestern New Mexico. The unconformity overlies the Owl Rock Member in most of northeastern Arizona and overlies older parts of the Chinle Formation to the west in Nevada and to the east in northwestern New Mexico. In southeastern Utah the unconformity probably lies at the base of rocks equivalent to the Hite Bed, where present, or at the base of the Wingate Sandstone.
\end{abstract}

\section{INTRODUCTION}

Part of the Upper Triassic rocks of northeastern Arizona and adjacent areas (fig. 1) includes the Chinle Formation and the overlying Wingate Sandstone. The uppermost subdivision of the Chinle Formation, in the Monument Valley area, is the same unit that, in the Defiance Plateau area, is assigned to the basal part of the
Wingate Sandstone. Geologic studies by the author in parts of southeastern Utah and northeastern Arizona have yielded some new information on the stratigraphic relations of these rocks. The purpose of this report is to review the nomenclature and to summarize the available information about the Upper Triassic stratigraphy of the area. This report proposes no changes in the existing nomenclature, but the information presented herein may help to resolve this conflict in nomenclature.

The author is grateful to R. A. Cadigan, M. E. Cooley, L. C. Craig, J. H. Stewart, J. D. Strobell, and D. G. Wyant for helpful suggestions and comments about terminology and regional geology made during a field conference in Monument Valley. The author expresses particular thanks to D. G. Wyant, who first recognized the significance of an important unconformity within the rock units discussed in this report. J. H. Stewart aided in measuring a stratigraphic section and examined some of the stratigraphic relations herein described, but he does not necessarily agree with any of the conclusions in this report.

The work on which this report is based is part of a continuing study of the geology of the Navajo Indian Reservation and was done on behalf of the U.S. Bureau of Indian Affairs in cooperation with the Navajo Tribe.

\section{STRATIGRAPHY}

Stratigraphic subdivisions recognized by Gregory (1917, p. 37-50) in northeastern Arizona and adjacent parts of southeastern Utah include, in ascending order, the Shinarump Conglomerate, the Chinle Formation, and the Wingate Sandstone. Gregory (1917, p. 42-43) distinguished four units (fig. 2) of the Chinle Formation, which he referred to as divisions $\mathrm{D}, \mathrm{C}, \mathrm{B}$, and A in ascending order. Gregory later $(1950$, p. 67) used the name Petrified Forest Member in the Zion Park 


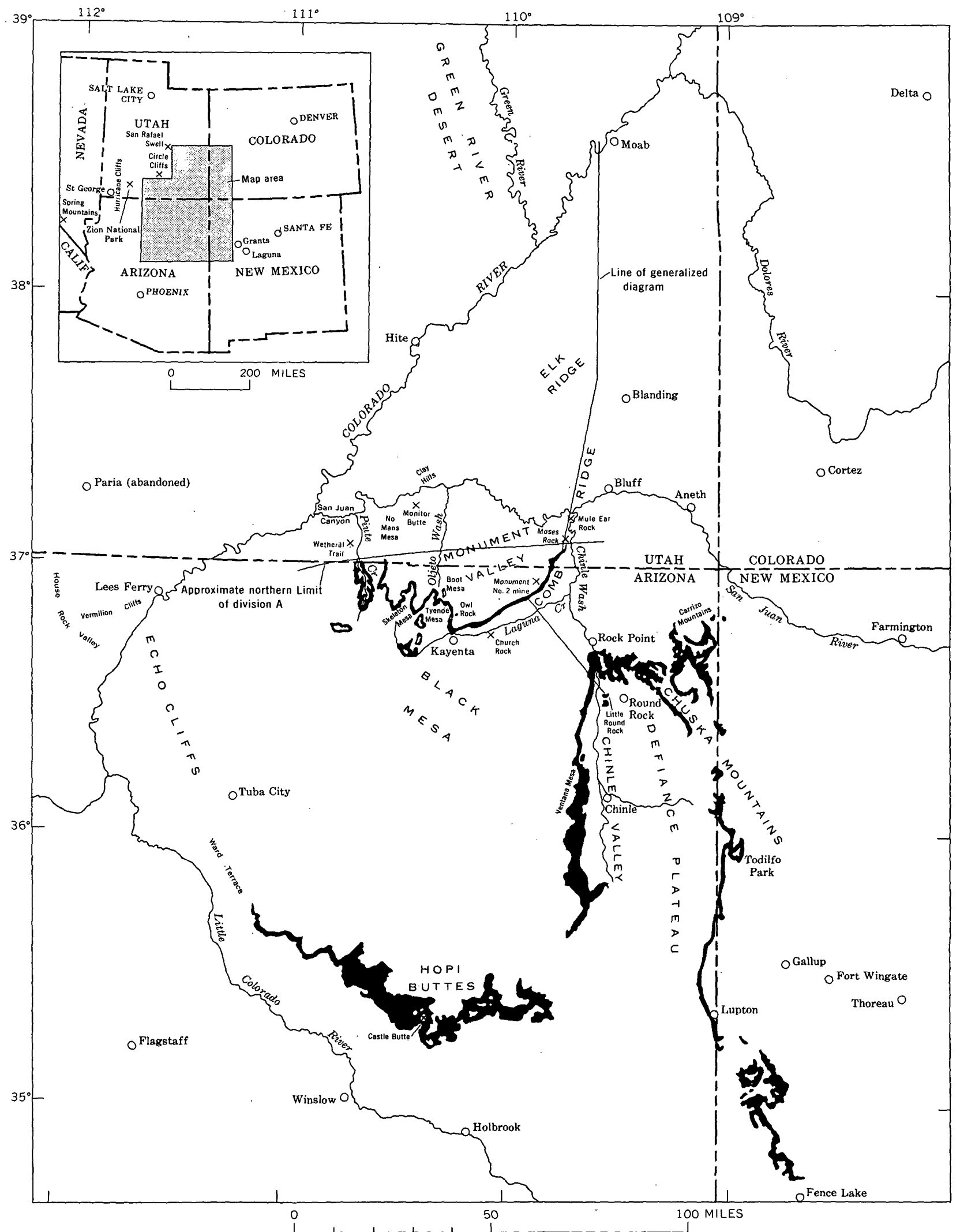

FrguRe 1.-Map of northeastern Arizona and adjacent areas showing approximate outcrop distribution of division A (solid). Compiled in part from Dane and Bachman (1957) ; Cooley, Harshbarger, Akers, and Hardt (1964) ; and M. E. Cooley (written commun., 1966). Base from U.S. Geological Survey, 1:1,000,000 State base maps. 


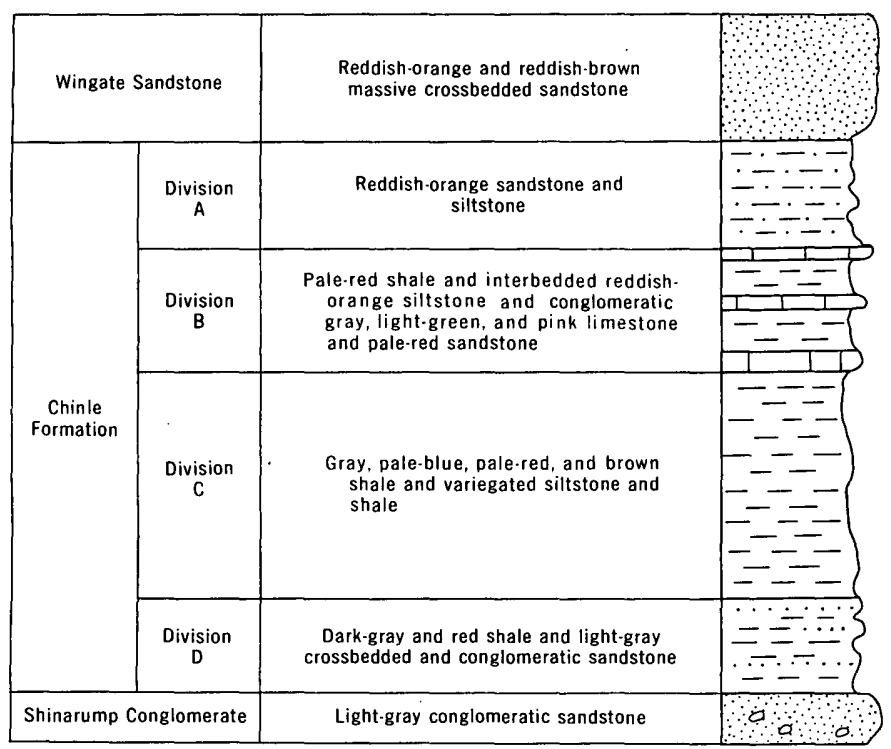

Frgure 2.-Nomenclature of Chinle Formation and related rocks of Gregory (1917).

area of southwestern Utah, and this name is now applied to his division C. In a series of reports describing the geology of southeastern Utah and the Monument Valley area of Arizona (Stewart, 1957; Stewart and others, 1959; Witkind and Thaden, 1963), formal member names were given to the other lettered subdivisions of the Chinle. The name Owl Rock was applied to division B, and Monitor Butte, to division D. The Shinarump Conglomerate was reduced to member status and assigned to the Chinle Formation.

The uppermost unit of the Chinle Formation or division A of Gregory, however, has been given two different names and assigned to two different formations. Division A was originally defined by Gregory (1917, p. 42) as the highest strata of the Chinle, and the type localities were given as Mesa de Ventana (now Ventana Mesa) and Todilto Park in the Defiance Plateau area. Harshbarger, Repenning, and Irwin (1957) removed division $\mathrm{A}$ from the Chinle Formation and assigned it as the lower member of the Wingate Sandstone (Rock Point Member) at Little Round Rock in the Defiance Plateau; the remaining upper part of the Wingate was named the Lukachukai Member. At this locality the base of the Wingate was placed at the top of division B (Owl Rock Member). Witkind and Thaden in a later report (1963, p. 22) named division A the Church Rock Member in the Monument Valley area of Arizona and left it in the Chinle Formation.

As a result of the different assignments of division A, an arbitrary decision was made. "North of Laguna Creek ***, division A (of the Chinle) is known as the Church Rock Member of the Chinle Formation.
South of Laguna Creek the same sequence of strata is to be known as the Rock Point Member of the Wingate Sandstone" (Witkind and Thaden, 1963, p. 34). Although two different names are used for division $\mathbf{A}$, there appears to be no dispute about the correlation of the unit across Laguna Creek (fig. 1) in northeastern Arizona.

Stewart, Williams, Albee, and Raup (1959, p. 518) recognized, in addition to these formal members, another unit-the Hite Bed-at the top of the Chinle and below the Wingate Sandstone over a large part of southeastern Utah. The Hite Bed in much of Utah is $10-50$ feet thick and consists of pale-red and light-greenishgray very fine grained sandstone and interbedded lenses of pale-reddish-brown siltstone. It locally contains trough sets of cross-strata and conglomeratic sandstone lenses which are composed of granules, pebbles, cobbles, and boulders. Previously a sandstone bed similar to the Hite Bed was noted in part of the Monument Valley area, but the relation of this sandstone to the Hite Bed as recognized to the north in southeast Utah was unknown (Stewart and others, 1959, p. 518). Work described here indicates that the Hite Bed is widely distributed in Monument Valley and consists of recognizably different upper and lower parts. The upper part of the Hite Bed is probably present everywhere in the Monument Valley area below the cliff-forming Wingate Sandstone. The lower part of the Hite Bed is only locally present.

The Wingate Sandstone is the oldest formation of the Glen Canyon Group, which includes, in addition, the Moenave and Kayenta Formations of Triassic(?) age and the Navajo Sandstone of Triassic(?) and Jurassic age. Harshbarger, Repenning, and Irwin (1957) described these units in detail.

\section{STRATIGRAPHIC RELATIONS IN SOUTHERN MONUMENT VALLEY}

The southern Monument Valley area of Arizona has been mapped and described by Witkind and Thaden (1963). The Chinle Formation in this area consists of five members, but only the upper two members-the Owl Rock and overlying Church Rock-are discussed here.

The Owl Rock Member ranges in thickness from 120 to 166 feet (Witkind and Thaden, 1963, p. 30-32) and is characterized by pale-red shale and minor ledges of limestone and sandstone. At the type locality the member is 166 feet thick (Witkind and Thaden, 1963, p. 31) and is made up of six limestone beds, 2-19 feet thick, that form ledges; these ledges are separated by slopeforming beds of mudstone or shale as much as 30 feet thick. 
In the same area the overlying Church Rock Member (Witkind and Thaden, 1963, p. 32-34) consists dominantly of a slope-forming sequence of reddishorange to reddish-brown siltstone and some sandstone. The following section measured by Witkind and Thaden $(1963$, p. 33) is considered to be typical.

Section of Church Rock Member of Chinle Formation measured on Comb Ridge about $61 / 2$ miles northeast of Kayenta, Ariz.

Wingate Sandstone.

Chinle Formation:

Church Rock Member:

Thickness

11. Siltstone, reddish-brown, fissile, even-bedded; weathers to form nodular ledges_-_-_--.--

10. Siltstone, reddish-brown, crossbedded ; locally interbedded lenses of fissile shaly siltstone_

9. Sandstone, grayish-brown, crossbedded, coarse-grained; includes granules as much as a quarter of an inch in diameter; thin discontinuous seams of chocolate-brown siltstone along bedding planes

8. Siltstone, reddish-orange altering locally to light-gray ; interbedded lenses of coarsegrained sandstone

7. Siltstone, reddish-orange, massive; weathers to form blocks about $2 \mathrm{ft}$ on a side

6. Siltstone, reddish-orange to reddish-brown, even-bedded; slightly fissile; mottled surface covered with light-gray spots about 2 in. across

5. Siltstone, reddish-brown, even-bedded; locally discontinuous; gray spots irregularly distributed over surface

4. Siltstone, reddish-orange, even-bedded, extremely fissile; locally interbedded with massive crossbedded siltstone beds

3. Siltstone, reddish-orange, fissile; locally discontinuous

2. Siltstone, reddish-brown; even-bedded although locally crossbedded; weathers as blocky ledges.

1. Sandstone, light-tan to light-brown, thinbedded, platy, faintly ripple-marked.

Total Church Rock Member--_-- 246

Owl Rock Member.

For purposes of correlation the author recognizes a tripart subdivision in this section. The upper 47 feet in part consists of coarse-grained crossbedded sandstone, which contains granules as much as a quarter of an inch across. This upper sequence (units 8 through 11) is here assigned to the upper part of the Hite Bed. The medial silty part of the Church Rock Member underlies the upper part of the Hite Bed and is 193 feet thick (units 2 through 7 ). The ripple-marked 6 -foot sandstone bed (unit 1) at the base is tentatively assigned to the lower part of the Hite Bed.

The name Hite Bed was not used by Witkind and
Thaden (1963) for rocks in the southern Monument Valley area of Arizona. The Hite Bed, however, can be recognized in their description of the upper part of the Church Rock Member. They (Witkind and Thaden, 1963 , p. 33) described the contact with the Wingate Sandstone as a change from "a parallel and crossbedded deposit with depositional features typical of fluvial deposits, to a massive deposit marked by large sweeping cross-laminae commonly attributed to eolian deposits." The fluvial deposits below the Wingate are considered to be the Hite Bed.

In southern Monument Valley the thickness of the upper part of the Hite Bed varies. It is 11 feet thick at the Arizona-Utah State line on Comb Ridge, 47 feet thick where typically exposed $61 / 2$ miles northeast of Kayenta, Ariz., and about 42 feet thick at Owl Rock, Ariz. (M. E. Cooley, written commun., 1967). The Hite Bed thins westward from Owl Rock, and a thickness of

the
only 2 feet was measured by the author at the north tip of 'Tyende Mesa on the east side of Oljeto Wash about $11 / 2$ miles south west of Boot Mesa.

The silty part of the Church Rock Member forms a reddish-brown to reddish-orange ledgy slope below the upper part of the Hite Bed. The silty part constitutes most of the Church Rock Member and is 193 feet thick where typically exposed $61 / 2$ miles northeast of Kayenta. It is 191 feet thick at Owl Rock (M. E. Cooley, written commun., 1967). The silty part of the Church Rock Member is equivalent to division $\mathbf{A}$ as recognized by Gregory at his type locality in the Defiance Plateau area and is therefore equivalent to the Rock Point Member of the Wingate Sandstone. For convenience and simplicity, the silty part of the Church Rock and the equivalent Rock Point Member of the Wingate will generally be referred to as division $\mathbf{A}$ in this report.

In most of southern Monument Valley the lower part of the Hite Bed is not conspicuous, and the unit appears to be restricted to the outcrops along Comb Ridge. The lower part of the Hite Bed is about 20 feet thick from the Arizona-Utah State line to the Monument No. 2 mine area. It possibly is 6 feet thick where exposed $61 / 2$ miles northeast of Kayenta.

\section{STRATIGRAPHIC RELATIONS IN NORTHEASTERN MONUMENT VALLEY}

North of the Utah State line in northeastern Monument Valley the Chinle Formation is complicated by additional lithologic units that wedge into the upper part of the formation. The correlation of these units, as shown on the accompanying line of sections (fig. 3), is based primarily on geologic mapping (O'Sullivan, $1965)$ of the area but incorporates some later, more detailed studies of the rocks so well exposed along Comb 
Ridge in this part of Monument Valley. From the vicinity of the Monument No. 2 mine, the line of sections trends northward along Comb Ridge for a distance of about 29 miles. A section (fig. 3, No. 16) near Church Rock in Arizona is also included.

\section{OWL ROGK MEMBER}

Along Comb Ridge, in northeastern Monument Valley, the Owl Rock Member consists mainly of pale-red shale. Delicate pastel pink and reds of the Owl Rock contrast sharply with the darker blue and gray of the underlying Petrified Forest Member and with the reddish orange of the overlying units. The shale is generally silty and calcareous, and much of it is spotted light greenish gray. Interspersed with the shale are several ledge-forming beds of limestone, sandstone, and siltstone. The limestone, in beds from less than 1 foot to 8 feet thick, is light greenish gray to light gray and at places is mottled pale red. The sandstone, in beds from 1 to 10 feet thick, is brown and pale red, fine to coarse grained, and at places contains pebbles of limestone and shale as much as 4 inches across. A tentative correlation of some of these beds for a distance of about 8 miles north of Monument No. 2 mine in an area mostly covered by windblown sand is shown in figure 3 (sections 15$10)$.

Where best exposed at a locality about $21 / 2$ miles north of Moses Rock (fig. 3, section 4), the Owl Rock Member is 414 feet thick and contains five ledges. The ledges in this area, however, tend to be nonpersistent and lenticular, and, as a result, the number and arrangement of the ledges vary from place to place. The base of the Owl Rock Member is arbitrarily placed below the lowest prominent ledge of sandstone or limestone.

\section{REDDISH-ORANGE SILTSTONE MEMBER}

The upper part of the Owl Rock Member in the area north of Moses Rock grades laterally into a sequence of reddish-orange siltstone beds (fig. 3). These beds are recognized by Stewart $(1957$, p. 459$)$ as part of his Church Rock Member of the Chinle over wide areas of southern Utah. For reasons that will be discussed, this so-called Church Rock in Utah is not a correlative of the type Church Rock in Arizona. In this report, for convenience, this sequence of beds will be referred to as the reddish-orange siltstone member.

The reddish-orange siltstone member forms a banded slope due to the alternation of hard and soft layers. The member is composed mainly of coarse silt-sized quartz grains, but it contains some grains of very fine sand size. At places, beds of pale-red and brown shale similar to the main part of the Owl Rock Member are interbedded with the siltstone. This interbedding is interpreted as an interfingering of lithology typical of 375-048 0-70-2 the reddish-orange siltstone member to the north with lithology typical of the Owl Rock Member to the south.

Although most of the reddish-orange siltstone member passes laterally southward into the upper part of the Owl Rock near Moses. Rock, some ledges of reddishorange siltstone or sandstone persist farther south. A reddish-orange ledge at Moses Rock may represent a southern extension of the reddish-orange siltstone member, or it may represent a separate lentil within the Owl Rock. The ledge, which is 6 feet thick and consists of very fine grained silty sandstone, is 64 feet below the top of the Owl Rock Member. Similar beds have been noted elsewhere in the Owl Rock Member at a few places to the south.

\section{MULE EAR LEDGE}

A prominent cliff-forming sandstone bed overlies the reddish-orange siltstone member throughout most of the area, but it also rests on the Owl Rock Member for a short distance near Moses Rock. This sandstone bed has previously been called the lower ledge (O'Sullivan, 1965 , p. 59), but in this report it is referred to as the Mule Ear ledge of local usage. The Mule Ear ledge is reddish orange, massive, and generally very fine grained and is commonly stained with a black manganese coating. Its base is marked by a sharp topographic break from the slope-forming underlying unit-either the reddish-orange siltstone member or the Owl Rock Member-to the cliff-forming Mule Ear ledge.

The Mule Ear ledge forms an easily recognized marker bed high on the west wall of Comb Ridge for a distance of about 27 miles northward from Moses Rock. In this distance it varies somewhat in thickness. It is thickest, 130 feet, at Moses Rock, but within 1 mile southward it is beveled out by an unconformity at the base of the next overlying unit. The Mule Ear ledge is 92 feet thick $21 / 2$ miles north of Moses Rock and 63 feet thick about 2 miles north of the San Juan River. At a point about 18 miles north of the San Juan River and beyond the limits of the area studied in detail by the author, equivalents of the Mule Ear ledge weather to a slope that merges with the underlying reddishorange siltstone member.

\section{HITE BED}

At Moses Rock (fig. 3, section 6) and in areas to the north, the Hite Bed is about 50 feet thick and consists of a uniform pale-red very fine grained crossbedded sandstone that forms a prominent cliff above the Mule Ear ledge. In color, composition, and bedding features the Hite Bed strikingly resembles the Kayenta Formation of Late Triassic(?) age, a unit that overlies the Wingate Sandstone. Because of this resemblance, the field term "Kayenta-like" has been applied to the Hite 
Bed by some geologists. The Hite Bed is 62 feet thick about 2 miles north of the San Juan River and about 30 feet thick in the area $21 / 2$ miles north of Moses Rock.

South of Moses Rock the Hite Bed contains thin lentils of reddish-orange sandstone or siltstone. Between sections 6 and 7 (fig. 3) the base of the Hite Bed unconformably channels down across the underlying Mule Ear ledge. At section 7 the Hite Bed is split into upper and lower parts by an intervening sequence of reddishorange siltstone, 27 feet thick, that represents the wedge edge of the silty part of the Church Rock Member or division $\mathbf{A}$.

The upper part of the Hite Bed south of Moses Rock is similar to all the Hite Bed to the north but is somewhat coarser grained. It commonly consists of fine- to medium-grained crossbedded pale-red sandstone. Locally, the Hite Bed contains beds of reddish-orange and pale-reddish-brown crossbedded sandstone. At places, reddish-brown siltstone pebbles and thin beds of reddish-brown siltstone or shale are also present. Individual

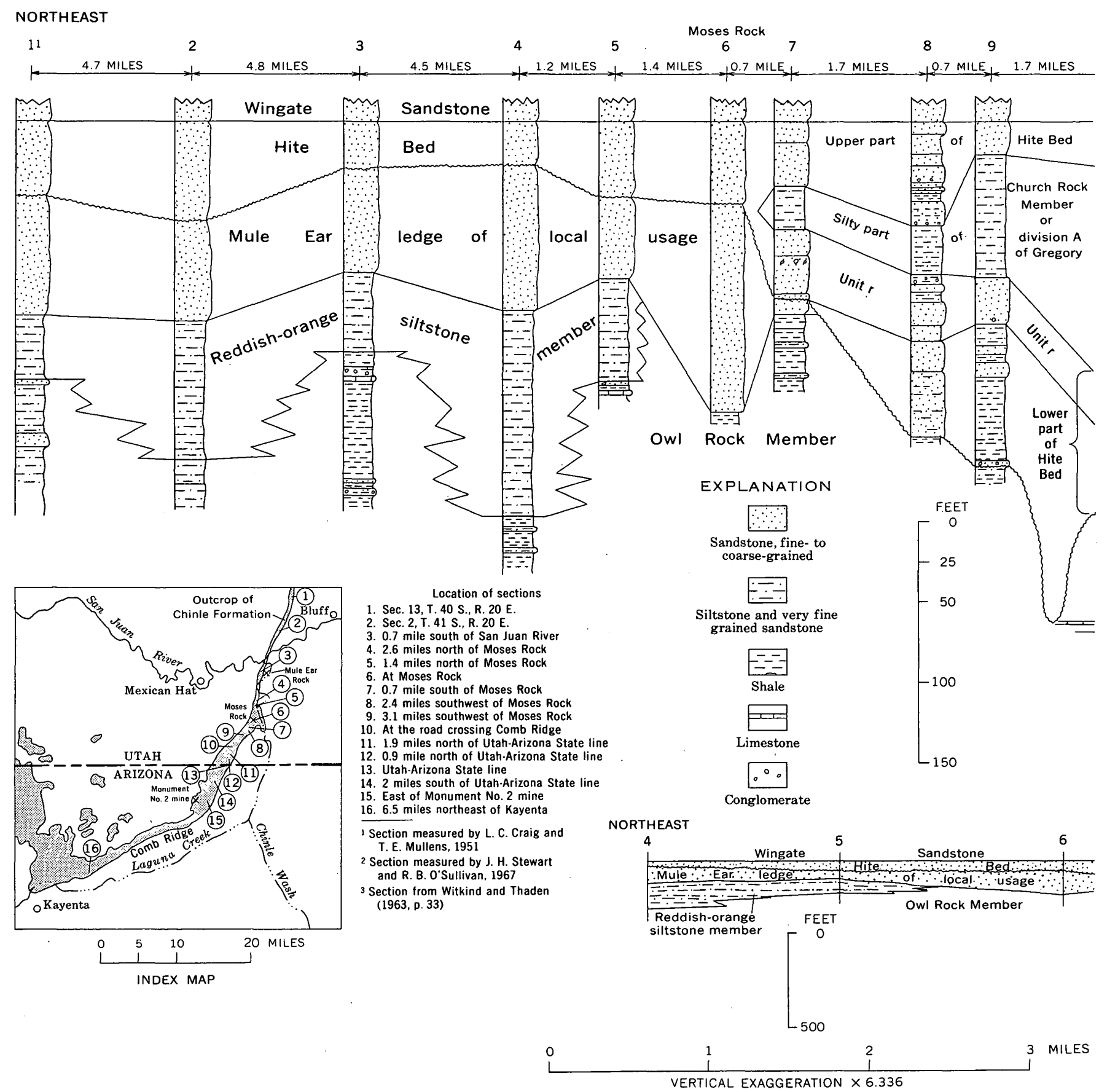

Frgure 3.-Graphic sections and stratigraphic diagram showing correlation 
sandstone beds tend to be lenticular and commonly fill channels cut into underlying units.

The lower part of the Hite Bed consists of a more heterogeneous assemblage of rocks than the upper part. One important reference bed (labeled "unit $r$ " on fig. 3) can be traced for about 5 miles along Comb Ridge. Between sections 9 and 10 it forms a prominent ledge and bench. The ledge dips eastward and is capped by spires and remnants of division A (fig. 4). The main outcrop of division $\mathbf{A}$ is eroded back to the east. Unit $\mathbf{r}$ is gen- erally pale red, typical of the color of the Hite Bed elsewhere in this area, but at places it is pale red brown and light greenish gray. It is crossbedded and flat bedded, consists of fine- to very coarse- grained sandstone, and is locally conglomeratic. The conglomerate at section 10 (fig. 3 ) consists of pebbles $3-4$ inches across which are limestone and sandstone and subordinate amounts of siltstone. Unit $r$ apparently terminates abruptly between sections 10 and 11 ; a thin conglomeratic sandstone at

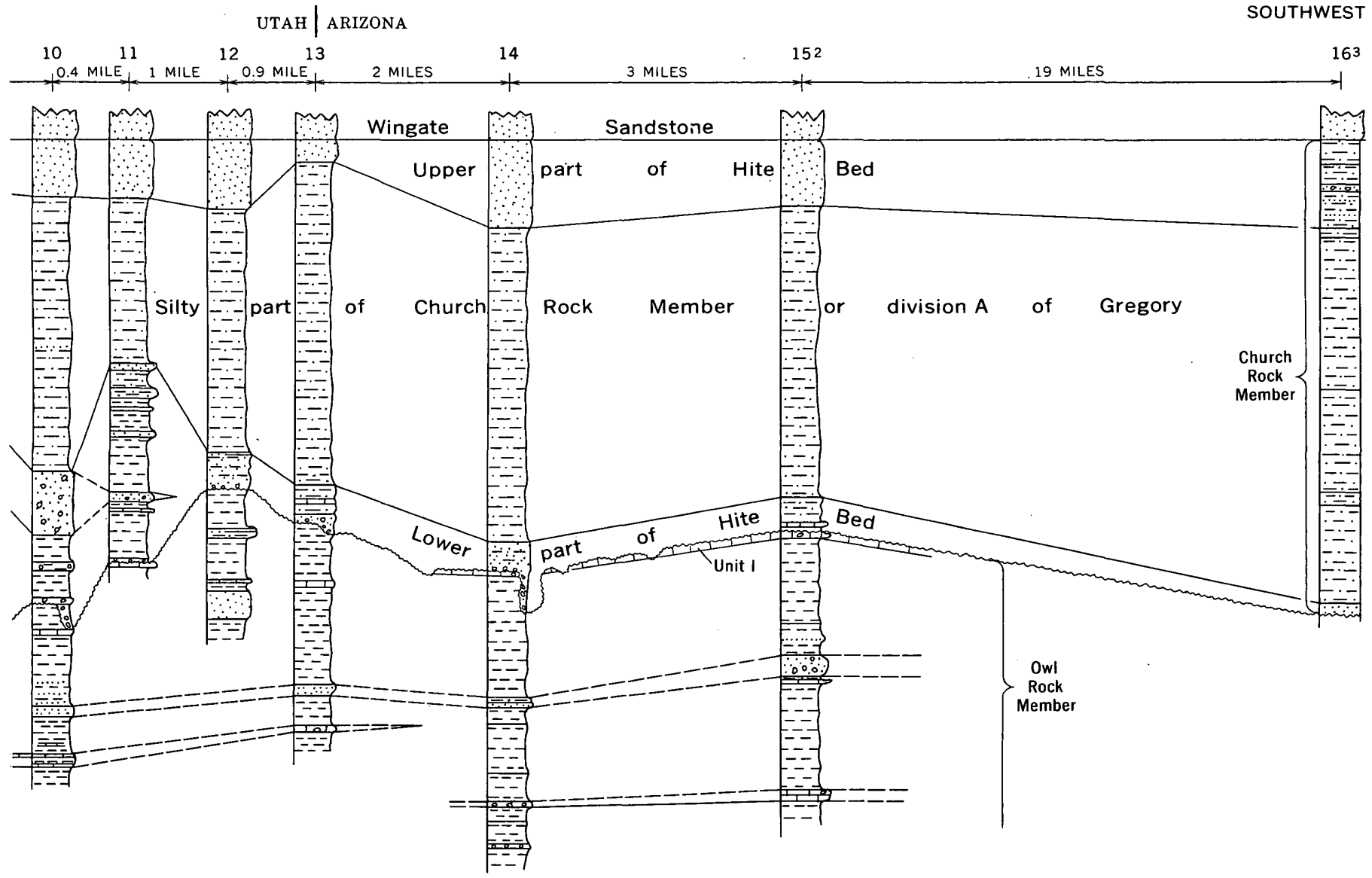

GRAPHIC SECTIONS

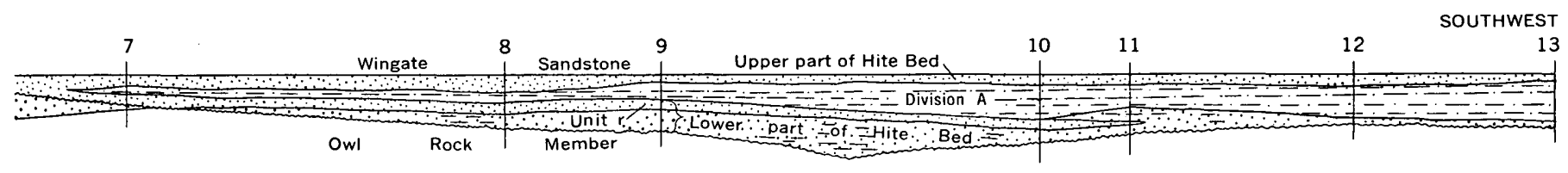

STRATIGRAPHIC DIAGRAM 


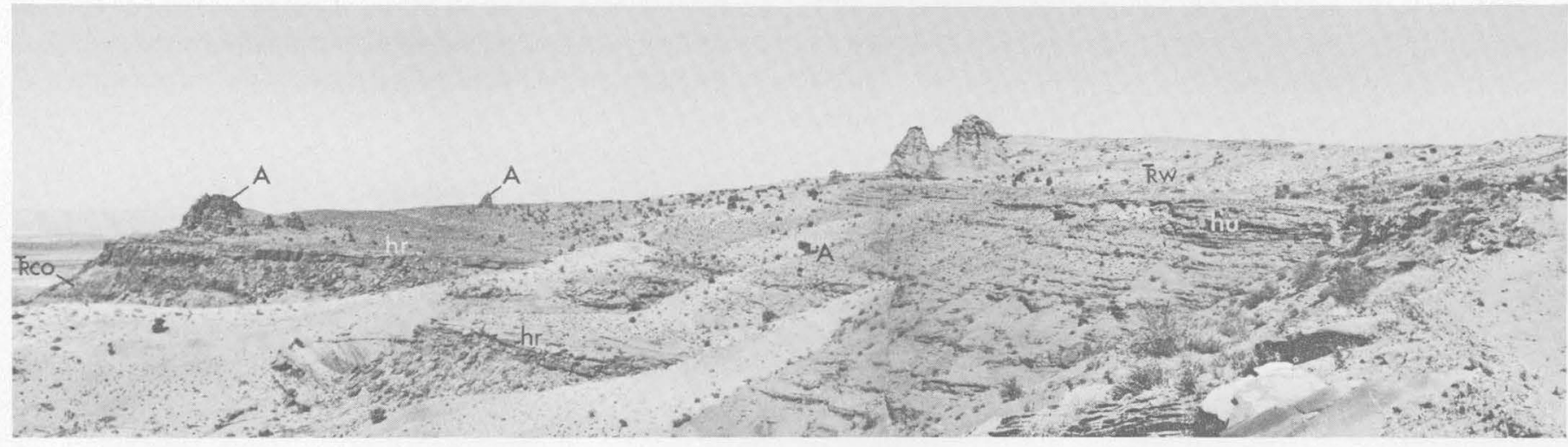

Figure 4.- Upper Triassic rocks along Comb Ridge. View north along road leading to Monument No. 2 mine. Owl Rock Member of Chinle Formation ( $\mathrm{kco}$ ); unit $\mathbf{r}$ of the lower part of Hite Bed (hr); division A (A); upper part of Hite Bed (hu); and Wingate Sandstone $\left(\mathrm{K}_{\mathrm{w}}\right)$.

section 11 may, however, represent a further continuation of unit $r$ to the south. (See fig. 3.)

From section 9 (fig. 3) northward to a point about $11 / 2$ miles north of section 8 , unit $r$ weathers back into a cliff that includes overlying rocks; but farther north toward Moses Rock, unit $\mathrm{r}$ again forms a bench. Between section 9 and Moses Rock (section 6) unit $\mathrm{r}$ consists of a complex assemblage of channeling sandstones. The sandstone beds are generally fine to very fine grained, pale red, grayish yellow, and dark yellowish brown with some interbedded reddish-brown shale or siltstone. Cobbles as much as half a foot across were noted near the middle of unit $\mathrm{r}$ at section 7 ; these cobbles resemble the conglomerate in unit $\mathrm{r}$ at section 10 .

The part of the Hite Bed below unit $r$ consists of a heterogeneous sequence of dark-reddish-brown, moderate-orange-pink, pale-red, and pale-reddish-brown silt- stone and shale and some very light gray and pale-red sandstone. Much of the lower part of the Hite Bed below unit $r$ appears to be material reworked from the Owl Rock Member of the underlying Chinle Formation. This part of the Hite Bed is characterized by great swales or channels (fig. 5) as much as half a mile wide and an estimated $30-40$ feet deep. These great swales are filled with smaller overlapping sets of channel deposits arranged in an intricate manner suggestive of large-scale crossbedding. The deposits in these smaller channels, which are as much as 100 feet across, consist of moderately cemented beds 3 inches to 3 feet thick separated by thin interbeds of softer rock.

At a point midway between sections 9 and 10 (fig. 3 ) and directly below unit $\mathbf{r}$ is a group of beds of deltaic origin which measure about 42 feet in thickness. The

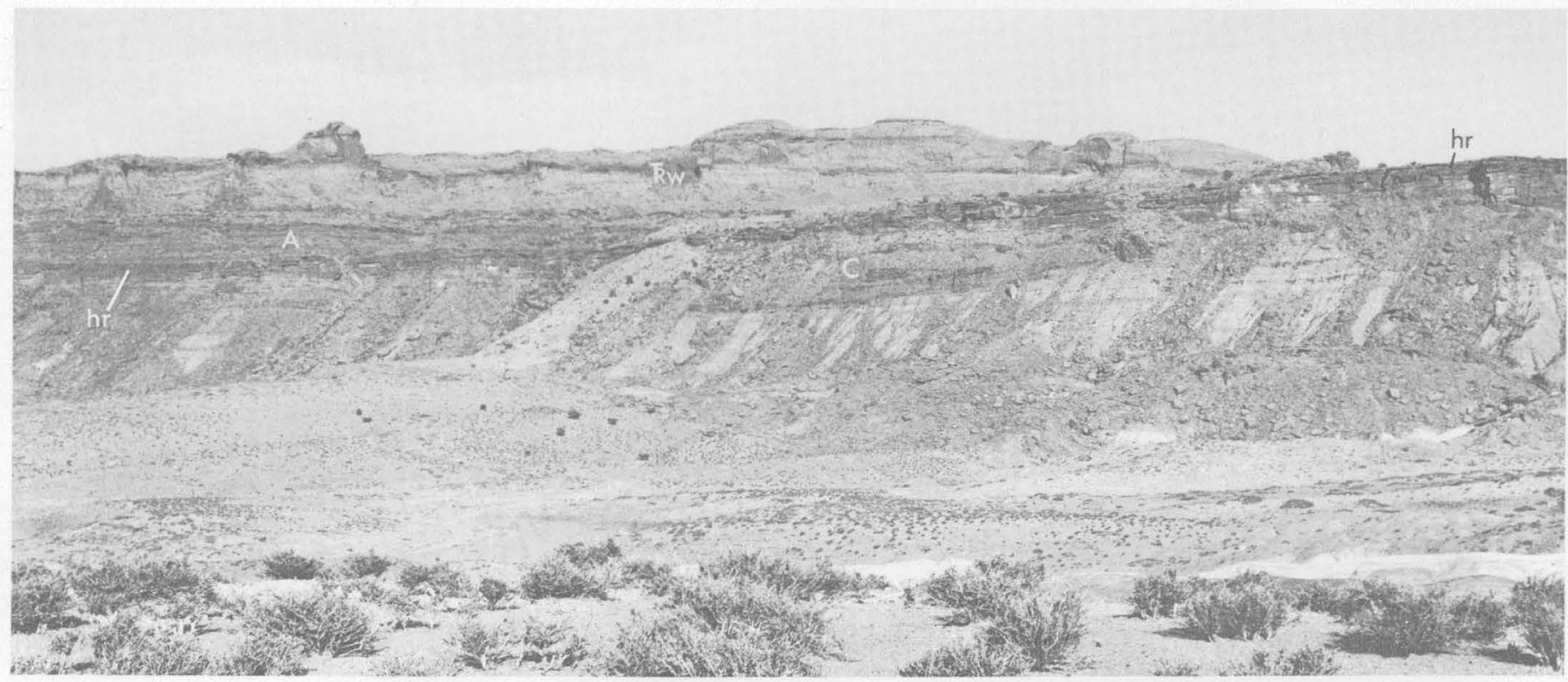

Figure 5.-West wall of Comb Ridge about 4 miles south of Moses Rock. Unit $r$ of lower part of Hite Bed (hr); division A (A); and Wingate Sandstone ( $\mathrm{kw}$ ). Note large channel (C) below unit $r$. 
foreset beds strike N. $87^{\circ} \mathrm{E}$. and dip as much as $30^{\circ} \mathrm{S}$. From areas of maximum dip the beds flatten rapidly into gently dipping bottomset beds in a distance of about 100 feet. Topset beds have been truncated by the overlying unit $r$. Similar deltaic beds were noted below unit $\mathbf{r}$ in the area between sections 7 and 8 .

The lower part of the Hite Bed thickens in a small area between sections 10 and 11 (fig. 3 ) at the expense of the overlying division $A$. At section 11 the lower part of the Hite Bed is about 102 feet thick and consists dominantly of reddish-brown and reddish-orange siltstone and shale and some thin sandstone beds. The overlying division $\mathbf{A}$ at section 11 is 85 feet thick, compared to 141 feet thick at section 10 about 0.4 mile to the north and 125 feet thick at section 12 about 1 mile to the south.

The lower part of the Hite Bed thins from section 11 (fig. 3) southward. It is 15-19 feet thick in the area from section 12 to section 15, in the vicinity of Monument No. 2 mine. In this area it consists mainly of darkreddish-brown to reddish-orange sandstone and siltstone and some thin light-gray to brown lenticular and platy limestone beds. At section 13 the lower part of the Hite Bed consists of beds 1-2 feet thick separated by shaly niches; at the base is a white and light-tan very finegrained to fine-grained sandstone, which contains some thin interbeds of shale. The basal sandstone is both crossbedded and flatbedded, forms a ledge, and contains pebbles of chert as much as 1 inch across in the lower part. Southward, at section 16 (fig. 3), the lower part of the Hite Bed may be represented by a 6 -foot ripplelaminated sandstone bed at the base of division $\mathbf{A}$.

\section{UNCONFORMITY AT THE BASE OF THE HITE BED}

Everywhere along Comb Ridge, between sections 1 and 15 (fig. 3), the Hite Bed is separated from the underlying rocks by an unconformity. Within the Hite Bed are numerous minor channeling erosional surfaces as would be expected in a fluviatile deposit. These minor erosional surfaces, however, cannot be traced regionally as can the widespread unconformity at the base of Hite Bed, as shown in figure 3.

North of Moses Rock the unconformity separates very fine grained massive sandstone of the Mule Ear ledge from crossbedded pale-red fine- to medium-grained sandstone of the Hite Bed. South of Moses Rock the unconformity at the base of the Hite Bed cuts across the underlying rocks, and the Hite Bed overlies the Owl Rock Member. In this area the Owl Rock Member is characterized by persistent units of uniform thickness than can be traced for a considerable distance. The beds just above the unconformity, particularly in the area between sections 8 and 10, are a heterogeneous sequence of channeling lenticular units of sandstone and siltstone.
Farther south, between sections 12 and 15, pebbles of chert and limestone commonly are present just above the unconformity in the base of the lower part of the Hite Bed. In the vicinity of sections 14 and 15 a conspicuous hackly-weathering limestone, which contains nodules of chert (fig. 3, unit 1), marks the top of the Owl Rock Member of the Chinle Formation. At several localities the unconformity cuts into or through unit 1 . The relations near section 13 are obscured by windblown sand, but the distinctive unit 1 cannot be recognized at section 13. At section 14 the unconformity cuts through unit 1 and into underlying beds of the Owl Rock Member in a channel about 20 feet deep. Boulders of rounded and angular limestone, many as much as 2 feet across, partly fill the south side of the channel. One slab of limestone about 4 feet across was found in the channel. The lithology of the boulders suggests that the boulders were derived from unit 1 .

For some distance to the south of section 14, small channels cut into or through unit $l$. The unconformity at the base of the lower part of the Hite Bed, however, gradually becomes less noticeable father south near section 15. At section 15, and from there for some distance to the south, the contact between unit 1 (the top of the Owl Rock Member) and the overlying beds is not marked by any channeling or by the presence of conglomerate. On the contrary, unit 1 appears to be a continuous bed that may extend over wide areas of Monument Valley as the highest limestone of the Owl Rock Member.

Witkind and Thaden (1963) regarded the Owl Rock and overlying Church Rock Members as partly intertonguing in southern Monument Valley. They have described stratigraphic relations they regarded as intertonguing in the vicinity of Monument No. 2 mine (fig. 3 , section 15 ), where the limestone that marks the top of the Owl Rock (unit 1 of this report) is "underlain by $* * *$ reddish-brown $* * *$ typical Church Rock strata" (Witkind and Thaden, 1963, p. 32). Siltstone, similar to that in the Church Rock Member (division A), is also present near Moses Rock in a 6-foot bed that is 64 feet below the unconformity at the top of the Owl Rock Member. Beds of similar siltstone have also been noted within the Owl Rock Member in the Chinle Valley area by the author, and in the Carrizo Mountains area, by Strobell (1956). These siltstone beds are not tongues that connect with the Church Rock, but they are either discrete lentils within the Owl Rock or southward-extending tongues of the reddish-orange siltstone member.

Although Witkind and Thaden (1963) described neither an erosional surface nor pebbles at the contact between the Owl Rock Member and overlying beds, such 
features are present at least locally in other parts of northern Arizona. In the Echo Cliffs area, Callahan (1951) reported that the Chinle Formation is in contact with overlying beds along an unconformity that is marked by conglomerate that consists of granules and pebbles of chert, limestone, siltstone, and mudstone. $\mathrm{He}$ stated $(1951$, p. 51$)$ that the conglomerate "has also been observed at Kayenta, Arizona, in the same stratigraphic position." The "same stratigraphic position" would be at the top of the Owl Rock Member, for the Owl Rock is the uppermost member of the Chinle in the Echo Cliffs area and near Kayenta. Beaumont and Dixon (1965, p. A6) have also noted reworked limestone pebbles locally at the contact of the Owl Rock Member and overlying beds in the Kayenta area. In southern Monument Valley, as already noted, a conglomerate unconformably overlies the Owl Rock Member for several miles between Monument No. 2 mine (fig. 3, section 15), and the Arizona-Utah State line.

Thickness relations suggest that the top of the Owl Rock in the southern Monument Valley area south of section 15 (fig. 3) is eroded. Regionally, the Owl Rock Member thins westward across northeastern Arizona. The Owl Rock is thickest, about 300 feet, along a line that trends from Round Rock southwestward to Castle Butte in the Hopi Buttes area (Akers and others, 1958, p. 94). It is 120-166 feet thick in the southern Monument Valley area of Arizona (Witkind and Thaden, 1963, p. 31). At Lees Ferry on the Colorado River, the Owl Rock Member is about 100 feet thick (M. E. Cooley, written commun., 1967). In southwestern Utah the Owl Rock is absent, largely owing to progressive westward erosional truncation at the top of the - Chinle Formation (Wilson, 1965, p. 35-36). Some of the differences in reported thicknesses of the Owl Rock Member may be due to disagreements by different geologists in placing the contacts, but a general thinning westward does seem apparent. The thinning of the Owl Rock Member across the Monument Valley area of Arizona is explained by a regional unconformity, even though the unconformity may not be evident at all outcrops in the Monument Valley area.

\section{DIVISION A}

Witkind and Thaden (1963, pl. 1) mapped their Church Rock Member, which includes division A (or the silty part of the Church Rock) and the upper and lower parts of the Hite Bed, around the east side of southern Monument Valley in Arizona to the Arizona-Utah State line. At the State line (fig. 3, section 13), division A is 166 feet thick and consists mainly of reddish-orange siltstone locally spotted light greenish gray. The unit forms a slope interrupted by ledges as much as 4 feet thick. Northward in Utah, division A thins between the upper and lower parts of the Hite Bed and is 77 feet and 27 feet thick, 3 miles and 1 mile south of Moses Rock, respectively. Division A wedges out into the Hite Bed just south of Moses Rock (fig. 3, section 6). Near the pinchout, siltstone beds of division A contain lentils of pale-red sandstone, lithologically like the Hite Bed, which make more abrupt the rapid lateral gradation of division A into Hite Bed. Vertical gradation has been noted at section 8 (fig. 3). At that locality the top of the lower part of the Hite Bed includes siltstone beds like those in division $A$, which are interbedded with sandstone beds like those that make up the main body of the Hite Bed.

\section{STRATIGRAPHIC RELATIONS IN NORTHWESTERN MONUMENT VALLEY}

The Church Rock Member, including the Hite Bed and the silty part or division A, was mapped around the south end of Monument Valley by Witkind and Thaden (1963, pl. 1) to Skeleton Mesa at the west edge of their area. From there northwestward, as shown on a geologic map accompanying a report by Cooley, Harshbarger, Akers and Hardt (1964), an equivalent unit labeled the Rock Point Member of the Wingate Sandstone has been traced as far as No Mans Mesa in Utah. M. E. Cooley (written commun., 1966) indicated, however, that division A does not extend this far north but disappears probably near the Utah-Arizona State line.

In Utah at the place where the Wetherill trail crosses Piute Creek about 6 miles north of the Utah-Arizona State line, division $\mathbf{A}$ is absent. At that locality the Hite Bed rests unconformably on the Owl Rock Member (D. G. Wyant, written commun., 1967). Hence, division A disappears between Wetherill trail and Skeleton Mesa. The reason for its disappearance has not been determined, but it may possibly grade into the Hite Bed in this area in much the same manner as division A grades into or pinches out in the Hite Bed along Comb Ridge on the east side of Monument Valley.

An approximate northern limit can be drawn for division A (fig. 1). The limiting line passes near the Utah-A rizona State boundary on the west side of Monument Valley and near Moses Rock on the east side of Monument Valley. As thus defined, division A extends not more than 8 miles into southeastern Utah.

In northwestern Monument Valley between the northern limit of division $\mathbf{A}$ and the San Juan River, the Hite Bed is present above the Owl Rock Member and below the Wingate Sandstone. The Hite Bed is 68.5 
feet thick in San Juan Canyon near the mouth of Piute Creek (M. E. Cooley, written commun., 1966). In a measured section (Mullens, 1960, p. 320-321) at Monitor Butte, it is 38 feet thick (J. H. Stewart, written commun., 1966). North of the San Juan River, the Hite Bed is locally present at least as far north as the junction of the Colorado and Green Rivers (J. H. Stewart, written commun., 1966).

The Chinle Formation has been mapped in the Clay Hills area near the San Juan River on the west side of Monument Valley (Mullens, 1960). In that area, Mullens (1960, p. 280-290) recognized three units of the Chinle above the Shinarump Member. The middle unit contains equivalents of the Owl Rock Member and most of the Petrified Forest Member. According to Mullens (1960, p. 287), the upper unit of the Chinle Formation

is as much as 190 feet thick and consists mainly of reddishorange interbedded siltstone and very fine-grained sandstone. Dense gray limestone and limestone-pellet conglomerate beds are sparsely distributed in the upper division, and locally the upper 10 to 40 feet of the upper unit consists of a pale-red medium-coarse to coarse-grained sandstone.

The pale-red sandstone just below the Wingate Sandstone and at the top of the upper unit of Mullens contains red mudstone pebbles. As described by Mullens $(1960$, p. 288), the pale-red sandstone "occurs in lenticular beds and is cross-laminated with the type of cross-laminations attributed to stream deposits." This sandstone is probably the Hite Bed (M. E. Cooley, oral commun., 1967).

Mullens (1960, p. 288-289) believed that the upper unit

correlates in general with the Church Rock member. However, the presence of limestone in the upper unit indicates gradation of Church Rock and Owl Rock members, and precludes an exact correlation of the upper unit with the Church Rock member. $*^{*} *$ The upper unit $* * *$ grades southwestward into an interbedded limestone and calcareous sandy siltstone sequence that cannot be separated from the middle unit of the *** Chinle in the southwest part of the map area.

The correlation of the upper unit with the Church Rock Member seems inappropriate inasmuch as the silty part of the Church Rock or division A has not been mapped as far north as the Clay. Hills area. The author interprets the upper unit of Mullens, excluding the locally present Hite Bed, to be equivalent to the reddish-orange siltstone member of this report and to grade to the southwest into the upper part of the Owl Rock Member of the Chinle Formation.

The stratigraphic relationships in the Clay Hills area in northwestern Monument Valley thus appear to be analogous to the stratigraphic relationships in north- eastern Monument Valley. Along Comb Ridge in northeastern Monument Valley, as described previously (fig. 3), the reddish-orange siltstone member or the Church Rock Member as used by Stewart grades southward into the Owl Rock Member which is stratigraphically below division $\mathbf{A}$.

The Clay Hills-San Juan Canyon area has been mapped by M. E. Cooley (written commun., 1966), and a summary description of the Chinle Formation and related rocks and a unit called the Church Rock Member of the Chinle Formation, which were mapped by Cooley, is contained in a report by Repenning, Cooley, and Akers (1965). They stated (Repenning and others, 1965 , p. 133-134) that "the member is composed of two units, which are separated roughly by a line trending west-southwestward through Monitor Butte." North of this line, "The rocks most typical of the Church Rock Member $* * *$ are pale red-purple $* * *$ to grayishorange pink $* * *$ sandy siltstone and silty sandstone beds which form a broken ledge-and-slope topography similar to that of the Owl Rock Member." South of the line, "the rocks assigned to the Church Rock Member are similar and stratigraphically equivalent to those of the Rock Point Member of the Wingate Sandstone ***."

The rocks north of the line that trends through Monitor Butte are equivalent to the reddish-orang. siltstone member of this report. The rocks south of the line are stratigraphically higher and are equivalent to the Church Rock Member (that is, division A and the Hite Bed) as defined by Witkind and Thaden (1963, p. 32-34).

\section{REGIONAL RELATIONS}

A generalized diagram (fig. 6) shows the author's interpretation of the stratigraphy of the Chinle Formation in parts of northeastern Arizona and southeastern Utah. The diagram represents the area that extends from Moab, Utah, southward along Comb Ridge in the area just described, to Round Rock, Ariz. The reddishorange siltstone member that replaces the upper part of the Owl Rock along Comb Ridge, together with the Mule Ear ledge, is a southward-extending tongue of a thicker unit that is present over wide areas of southeastern Utah. The reddish-orange siltstone member thickens northward below the Hite Bed or the Wingate Sandstone. In the Moab, Utah, area the reddishorange siltstone member is called the Church Rock Member and at places constitutes the entire Chinle Formation (see Stewart, 1957, fig. 4). As clearly shown by figures 3 and 6 , the reddish-orange siltstone member lies below the Hite Bed in the Monument Valley area and 


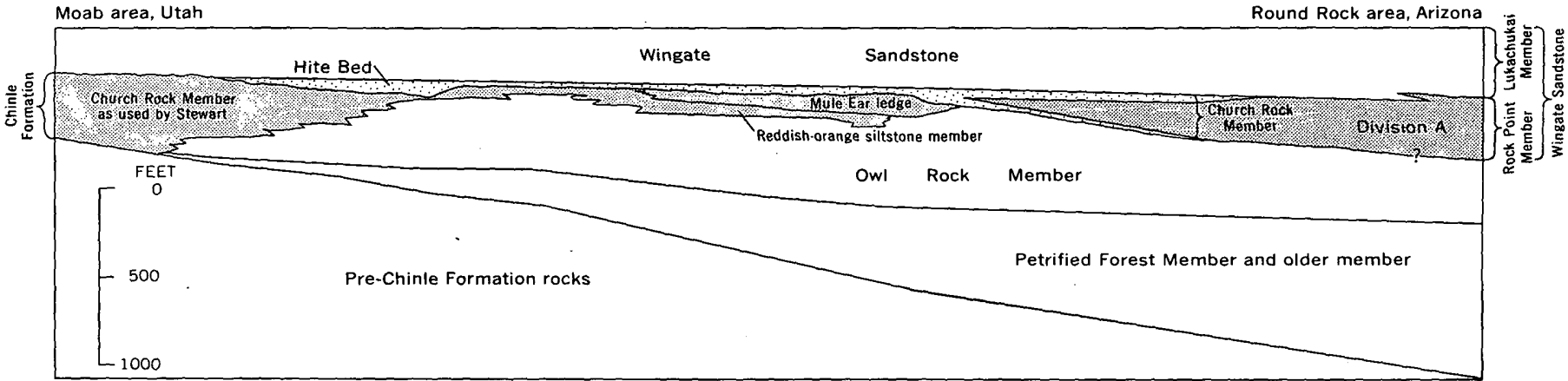

FIGURE 6.-Generalized diagram showing stratigraphic relations of Chinle Formation and related rocks from the Moab, Utah, area to the Round Rock, Ariz., area. Diagram in part from Stewart (1957, fig. 4; written commun., 1966) and Repenning, Cooley, and Akers (1965, fig. 5).

is, therefore, stratigraphically lower and older than Gregory's division A. The reddish-orange siltstone member is confined to southeastern Utah and apparently is best developed north of the San Juan River, although along Comb Ridge the southward-extending tongue of the member can be recognized as far southward as the vicinity of Moses Rock.

Although division A superficially resembles much of the reddish-orange siltstone member--the Church Rock Member as used by Stewart-the grain-size distribution, fossil content, clay mineralogy, paleogeography, and other regional relations of the two members strongly support the conclusion that the two are different units.

\section{GRAIN SIZE}

Outcrop samples have been collected from sedimentary rock -units in much of the Colorado Plateau by many geologists during an intensive program of field mapping and stratigraphic studies by the U.S. Geological Survey. These samples were examined by R. A. Cadigan, of the U.S. Geological Survey, for measurable characteristics of texture and composition. The analytical methods have been described by Cadigan (in Stewart and others, 1959; Cardigan, 1961). The author and R. A. Cadigan examined the results of the grainsize analyses for those samples from the upper part of the Chinle and related rocks, and some preliminary interpretations are presented here.

The samples have been rearranged (by the author) into two groups. One group comprises all the samples from division A (including the Rock Point Member and the equivalent silty part of the Church Rock Member of the southern part of Monument Valley). The other group contains the samples from the reddish-orange siltstone member of this report from southeastern Utah north of the San Juan River. The results are as follows:

\begin{tabular}{|c|c|c|c|c|c|}
\hline \multirow[t]{2}{*}{ Stratigraphic unit } & \multirow{2}{*}{$\begin{array}{l}\text { Number } \\
\text { of } \\
\text { samples }\end{array}$} & \multirow{2}{*}{$\begin{array}{l}\text { Mean } \\
\text { grain size } \\
\text { (milli- } \\
\text { meters) }\end{array}$} & $\begin{array}{l}\text { Standard } \\
\text { deviation }\end{array}$ & Skewness & Kurtosis \\
\hline & & & \multicolumn{3}{|c|}{ (phi units) } \\
\hline $\begin{array}{l}\text { Division A } \\
\text { Reddish-orange } \\
\quad \text { siltstone }\end{array}$ & 37 & 0.056 & 1. 527 & 1. 241 & 7. 308 \\
\hline member $\ldots$ & 42 & .053 & 2. 054 & .765 & 2. 33 \\
\hline
\end{tabular}

The reddish-orange siltstone member is, on the average, a coarse siltstone that is poorly sorted, slightly skewed, and moderately peaked. Division $\mathbf{A}$ is, on the average, a coarse siltstone that is moderately well sorted, moderately skewed, and moderately peaked. According to R. A. Cadigan (written commun., 1966) "On the basis of analysis of variance of the standard deviation of the grain-size distributions, the difference in sorting between the two groups of samples is significant at the 99-percent confidence level. Although untested, similarly significant differences probably exist also in grain size, skewness, and kurtosis."

The differences in sorting (derived from the standard deviation) and in skewness and kurtosis would be explained if division $\mathbf{A}$ accumulated at a slower rate than the reddish-orange siltstone member and was more thoroughly reworked (perhaps because of a slower rate of subsidence during deposition). In addition, division A probably accumulated in an environment of lower fluid velocities than the reddish-orange siltstone member. This probability is suggested by bedding features that indicate division $\mathbf{A}$ is a quiet-water deposit (Harshbarger and others, 1957, p. 9-10), whereas the reddish-orange siltstone member is partly fluviatile (Baker, 1933, p. 40; Schultz, 1963, p. C40; Witkind, 1964, p. 16-17). 


\section{CLAY MINERALS}

The clay minerals in Triassic rocks of the Colorado Plateau, including the rocks described in this report, are discussed by Schultz (1963). The clay-mineral distribution presented by Schultz indicates a difference in both source and composition of the clays in the reddishorange siltstone member (Church Rock Member as used by Stewart) in Utah as compared to division $\mathrm{A}$ in northeast Arizona.

Schultz (1963, p. C40-C43) showed that the Owl Rock and the overlying division A in northeastern Arizona are predominantly montmorillonitic in composition and in this respect closely resemble the underlying Petrified Forest Member. Moderate amounts of illite and chlorite are also present. Schultz (1963, p. C42) indicated that the principal source for the montmorillonitic clays was to the south.

Montmorillonitic rocks of the upper part of the Chinle Formation, including the reddish-orange siltstone member, become increasingly illitic in composition from Arizona north ward into Utah (Schultz, 1963, p. C42 and pl. 4). In the Moab area, illitic clays are dominant in the reddish-orange siltstone member (Church Rock Member as used by Stewart). Intermixed with the illitic rocks in the Moab area are a few percent of chlorite, generally to the east, and a few percent kaolinite, generally to the west. The distribution of the accessory kaolinite and chlorite indicates a source to the east (Schultz, 1963, p. C42). The theory of an eastern source for the illitic clays is supported by the thickening of these rocks eastward and by studies of crossbeds (Schultz, 1963, p. C42).

\section{FOSSILS}

The distribution and relative abundance of fossils in the Chinle and related rocks give some help in differentiating division A. Camp $(1930$, p. 3$)$ noted that the lower part of the Chinle (divisions $C, D$ ) contains abundant fossil wood and vertebrate remains, but that such organic remains are sparse in the upper part of the Chinle (divisions A, B). In the Carrizo Mountains area, J. D. Strobell, Jr. (oral commun., 1966), pointed out that this relationship can be carried further and that organic remains are common in divisions $\mathrm{C}$ and $\mathrm{D}$, less common in division $\mathrm{B}$, and are not found in division $\mathbf{A}$.

Organic remains have been reported from division A on the southeast flank of the Carrizo Mountains (Harshbarger and others, 1957, p. 10) in an area where divisions A and B intertongue. According to Strobell, however (1956; oral commun., 1966), the lithology of these fossiliferous beds indicates that they should be classified as Chinle Formation (division B). Fragmentary vertebrate fossils have also been found at the base of division A near Lupton, Ariz: (Harshbarger and others, 1957 , p. 10,23), but these are in conglomeratic lenses of fluviatile origin that represent deposition marginal to the more typical facies of division $\mathbf{A}$.

No fossils, except worm trails (Harshbarger and others, 1957, p. 23), have been found so far in the siltstone facies typical of division A. This suggests that the area of deposition of division A (the Rock Point Lagoon, see fig. 8) was an inhospitable area for the growth or preservation of organisms. It has been inferred (Harshbarger and others, 1957, p. 23) that the water in which division A was deposited "was abnormal" and that "it may have been highly saline and of an oxidizing nature."

In southeastern Utah, fossils have been reported (Baker, 1933, p. 41; McKnight, 1940, p. 69-70; Mullens, 1960, p. 288) from throughout the Chinle Formation, including the upper part that contains the reddishorange siltstone member or Church Rock Member as used by Stewart. The fossils found in the reddishorange siltstone member of southeastern Utah are similar to the fossils found in the Owl Rock Member of northeastern Arizona. In summary, the presence of similar fossils in both the Owl Rock and the reddishorange siltstone member contrasts with the general absence of fossils from division $\mathbf{A}$.

\section{CHINLE FORMATION-GLEN GANYON GROUP CONTACT}

In a large area that includes parts of Arizona, Utah, and New Mexico, the author places the contact between the Chinle Formation and Glen Canyon Group at a well-defined horizon that probably everywhere is an unconformity, which marks an important regional break in sedimentation in the Upper Triassic Series. In northeastern Arizona and adjacent areas this contact is at the top of the Owl Rock Member. In southeastern Utah, beyond the limits of the Owl Rock Member, the contact is placed at the top of the laterally equivalent reddish-orange siltstone member. In the southwestern Utah and in parts of northwestern New Mexico, it is at the top of the Petrified Forest Member. Different units of the Glen Canyon Group overlie the Chinle Formation. The relationships of the various units above and below the unconformity at the top of the Chinle Formation are shown in figure 7.

At many places in northeastern Arizona the contact between division $\mathrm{A}$ and the Owl Rock Member appears to be conformable, but the author believes that the con- 


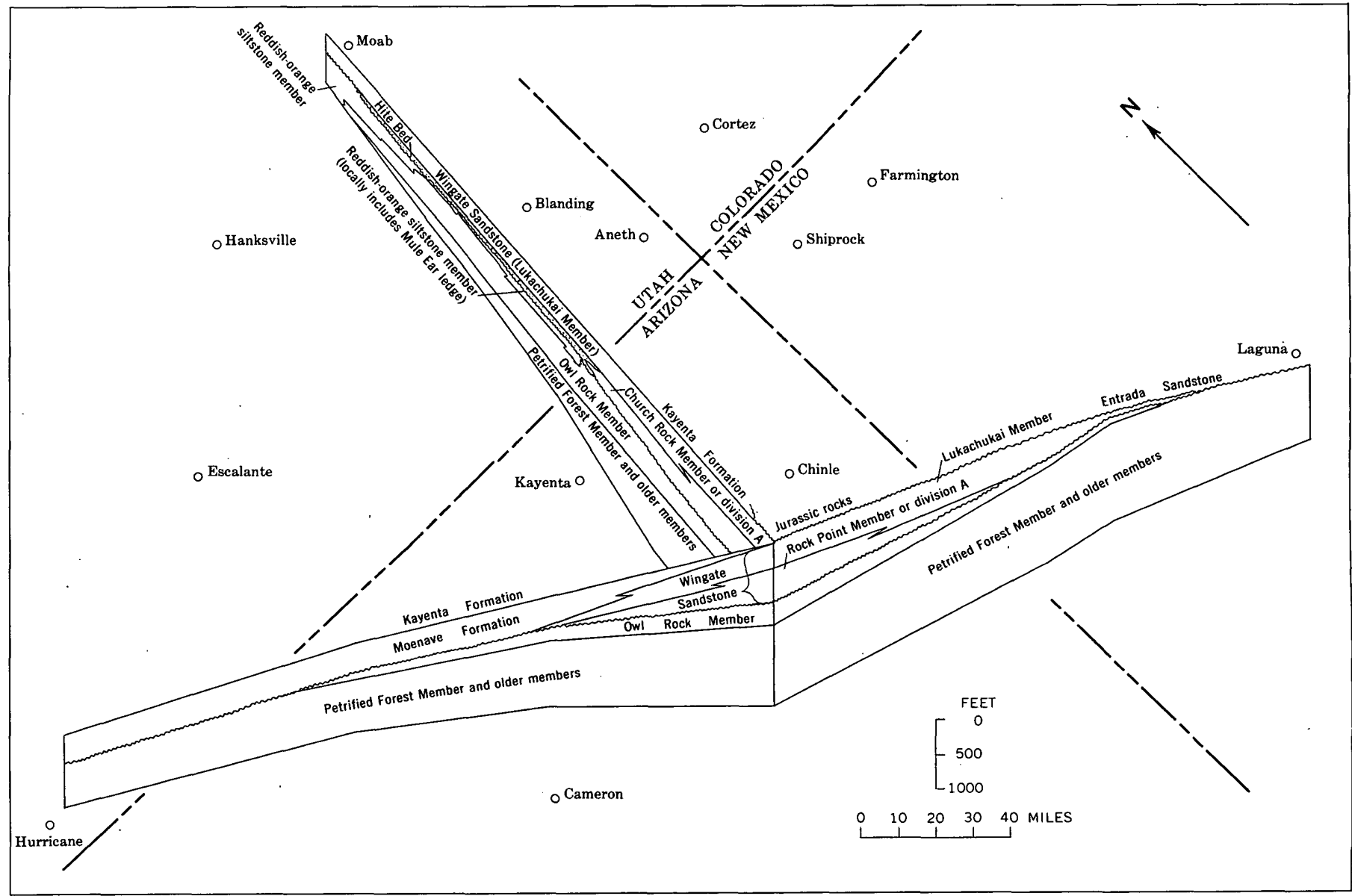

FIGURE 7.-Generalized fence diagram of Chinle Formation and related rocks. In part from Stewart (1957); Harshbarger, Repenning and Irwin (1957); Akers, Cooley, and Repenning (1958); Wilson and Stewart (1967).

tact is sharp and that it records an abrupt change in lithology. At other places the basal contact of division A and basal units of the Glen Canyon Group, where they rest on the Chinle, is marked by an erosional surface, which generally shows minor relief and which is overlain by a thin conglomerate composed of pebbles reworked from the Chinle Formation. The basal conglomerate has been noted locally in the Chinle Valley area and near Round Rock (Akers and others, 1958, p. 94). In the Ward Terrace-Echo Cliffs area (see fig. 1 for geographic location), the Moenave Formation overlies the Owl Rock Member. The basal contact of the Moenave is described as an unconformity, which shows minor relief. The basal bed of the Moenave is a thin conglomerate 2-3 inches thick, which consists of pebbles derived from the Chinle Formation (Harshbarger and others, 1957, p. 13, 15). Along Echo Cliffs the unconformity, overlain by the basal conglomerate, is represented by a gently rolling surface on the Owl Rock Member commonly with as much as 2 feet of relief within a few feet laterally (Callahan, 1951, p. 51). Near Tuba City the unconformity at one place is the base of a stream channel 12 feet deep and 40 feet aoross, which is filled with large cobbles and pebbles of reworked Chinle (Callahan, 1951, p. 51).

In the Lees Ferry area an unconformity between the Owl Rock Member of the Chinle Formation and the Glen Canyon Group has been described by Phoenix (1963, p. 23-27). Basal beds of the Glen Canyon Group, which contain small chips of green and red chert and flakes of mudstone probably derived from the Chinle Formation, fill scour structures along the unconformity. At places, a zone of sandstone as much as 10 feet thick above the unconformity is bleached white. Locally, beds in the Owl Rock Member directly below the unconformity have been silicified to light-pink chert, which contains masses of grayish-green chalcedonic chert and stringers and veinlets of red jasper.

Northwest of Lees Ferry in southwestern Utah, in a large area extending from Paria town site (now abandoned) on the east to St. George on the west, the unconformity between the Glen Canyon Group and the Chinle Formation has been discussed by Wilson (1965). In describing the unconformity, Wilson (1965, p. 35-36) 
states: "Higher members of the Chinle, such as the Owl Rock and Church Rock Members of southeastern Utah, are absent in southwestern Utah, largely as the result of a progressive westward truncation of the Chinle along an unconformity at the base of the overlying Glen Canyon Group."

The Church Rock Member of southeastern Utah mentioned by Wilson is the reddish-orange siltstone member of this report and the Church Rock Member as used by Stewart. Most of the reddish-orange siltstone member, as discussed, disappears by grading out southward and westward into the Owl Rock Member in the Clay Hills area rather than by erosional truncation. Any erosional truncation of the reddish-orange siltstone member would be at the base of the Hite Bed. The unconformity at the base of the Hite Bed probably is the same one as the unconformity at the base of the Glen Canyon Group discussed by Wilson.

According to Wilson (1965, p. 39), there is as much as 10 feet of erosional relief locally on the unconformity at the base of the Glen Canyon Group in southwestern Utah. The basal beds of the Glen Canyon Group commonly contain coarse grains and granules of quartz, quartzite, and chert and, at places, contain lag gravels, which were derived from the Chinle Formation and which consist of pebbles of quartz, quartzite, and chert.

The unconformity in an area that extends from the Hurricane Cliffs of Utah westward to southern Nevada has also been described by Wilson and Stewart (1967). They desoribed the Chinle Formation and Glen Canyon Group contact as "an erosion surface that marks *** an important stratigraphic break in the Upper Triassic Series" (Wilson and Stewart, 1967, p. D13). In describing this contact or erosional surface and the basal beds of the Glen Canyon Group directly over the unconformity, Wilson and Stewart (1967, p. D13, D14) stated:

the basal bed of the Glen Canyon Group or its probable equivalents consists of conglomeratic sandstone or of lenses of conglomeratic sandstone in a sandstone matrix. This bed ranges from 1 inch to 18 feet in thickness, and seems to be persistent unit. The conglomeratic material contains granules to cobbles of chert and lesser amounts of quartzite and quartz. Siltstone and limestone pebbles are common. In the Spring Mountains, a considerable amount of the conglomeratic material in this bed consists of volcanic rock fragments ***.

The pebbles in the basal bed of the Glen Canyon Group probably accumulated as lag gravel deposits on the erosion surface at the top of the Chinle Formation. ${ }^{*} *$ the pebbles probably were derived by reworking from the underlying Chinle Formation.

Topographic relief along the contact $* * *$ is not particularly noticeable ***. The contact surface is almost flat, and the average relief is not more than a few inches.
The Chinle Formation and the Glen Canyon Group have also been mapped and desoribed west of Lees Ferry along the Vermilion Cliffs and in the House Rock Valley area of Arizona (Wells, 1960; Petersen and Wells, $1960 ;$ Petersen, 1959, 1961). In the House Rock Valley area the Owl Rock Member is as much as 53 feet thick and pinches out southward (Wells, 1960, p. 123-124, pl. 4). The contact between the Glen Canyon and the Chinle Formation at the few places where it is exposed is conspicuous and sharp, but, because there is no apparent truncation of underlying beds and no channeling or basal conglomerate, the contact was considered by Wells (oral commun., 1969) to be conformable. In the adjacent Lees Ferry area to the east, however, the contact is better exposed, and it is described by Phoenix (1963) as an unconformity. The contact is also an unconformity to the north and west (Wilson, 1965; Wilson and Stewart, 1967). These relations strongly suggest that the base of the Glen Canyon Group is also an unconformity in the Vermilion Cliffs-House Rock Valley area of Arizona. The pinchout of the Owl Rock in the House Rock Valley, which is described by Wells (1960, p. 123-124), may be due to this unconformity. More work, however, needs to be done in this area to clarify the relationships.

Southeast of Monument Valley along the ArizonaNew Mexico State line, the Owl Rock Member of the Chinle Formation is overlain by division A. The contact between the two units is marked by a thin granule conglomerate, and near Lupton, Ariz., basal beds of division A contain several thick conglomeratic lenses (Harshbarger and others, 1957, p. 5). East of Gallup, N. Mex., in the Fort Wingate area, the Lukachukai Member of the Wingate Sandstone overlies the Owl Rock Member, and the basal contact of the Wingate is a channeled surface overlain by a 6 -inch granule conglomerate (Harshbarger and others, 1957, p. 11). Farther east near Thoreau, conglomerate occurs above the unconformity in channels that, have a relief of as much as 3 feet (Harshbarger and others, 1957, p. 5). In the Thoreau area the Owl Rock Member is overlain by a unit assigned to the Wingate(?) Formation (Smith, 1954). The basal beds of the Wingate(?) Formation are from a few inches to 8 feet thick and consist of siltstone reworked from the Chinle Formation; these beds contain coarse angular fragments of white chert and include channel deposits that fill a scour zone that is cut on the underlying Chinle (Smith, 1954, p. 11). Farther east, at a locality 9 miles northeast of Grants, N. Mex., the Wingate Sandstone rests unconformably on the Chinle Formation, and large mud cracks as much 
as 3 feet wide at the top of the Chinle are filled to a depth of at least 9 feet with sandstone from the overlying Wingate (R. E. Thaden, oral commun., 1969). Still farther east in the Laguna area, New Mexico, the Entrada Sandstone rests unconformably on the Petrified Forest Member. Basal beds of the Entrada locally include a quartz-pebble conglomerate that fills scours cut into the Chinle Formation (Moench, 1964b).

Post-Chinle erosion beveled the uplifted Chinle Formation in southwestern Utah and in the area east of Gallup, N. Mex. The Owl Rock Member of the Chinle Formation thins eastward from about 300 feet in northeastern Arizona to about 40 feet near Thoreau, Mex.; it also thins westward to a pinchout in the House Rock Valley area of Arizona. Some of the thinning may be depositional, but most of it is probably due to erosion beneath the overlying unconformity. A measure of the amount of truncation is indicated by the relation of the unconformity to the Correo Sandstone Bed of the Petrified Forest Member of the Chinle Formation. According to Smith (1954, p. 10), a reddish-brown crossbedded sandstone in the Thoreau area may correspond to the Correo. The questionable Correo in the Thoreau area is 364 feet below the unconformity at the top of the Chinle Formation (Cooley, 1959, p. 71). In the Laguna area the Correo is locally present directly below the unconformity at the top of the Chinle Formation (Moench, 1964a). The Correo is not present at places in the Laguna area, and its absence may be due to preEntrada erosion. If the Chinle was deposited uniformly across the area, and if the correlation of the Correo is correct between the Thoreau and Laguna areas, then about 360 feet of the Chinle Formation is beveled out between the two localities.

In southeastern Utah, units overlying the unconformity as herein described are either the Hite Bed or the massive Wingate Sandstone (equivalent to the Lukachukai Member of the Wingate in northeastern Arizona).

The Hite Bed is a distinctive unit that is present in much of southeastern Utah. The lower contact of the Hite Bed is a channeling surface of erosion. The upper contact with the massive Wingate Sandstone is generally sharp. The Hite Bed, however, intertongues with the overlying Wingate Sandstone in the Elk Ridge area. In describing the upper part of the Chinle Formation, Lewis and Campbell (1965, p. B19) stated, "The upper most 40 feet commonly includes from one to three beds of maroon medium- to coarse-grained sandstone, at least partly of fluvial origin, which locally intertongues with the lowermost part of the overlying Wingate Sandstone." The name Hite Bed was not used by Lewis and Campbell (1965), but the presence of this bed as the "maroon medium- to coarse-grained sandstone" is clear' from their description. Similar relations between the Hite Bed and the Wingate Sandstone have been noted elsewhere. According to D. G. Wyant (oral commun., 1968), the Hite Bed grades upward into the Wingate Sandstone in the Hite, Circle Cliffs, and Clay Hills areas.

In most of the Circle Cliffs area of south-central Utah (Davidson, 1967), the Wingate Sandstone rests on the Owl Rock Member of the Chinle Formation. Davidson (1967, p. 36) described the contact between the Wingate Sandstone and the Chinle Formation as

sharp and well defined with little or no relief, except in the Long Canyon area in the northwestern part of the Circle Cliffs area where 15-25 feet of poorly sorted fluvial sandstone beds forms the base of the Wingate and fills erosional pockets in the top of the Chinle.

Somewhat similar relations were noted at a measured section by Davidson $(1967$, p. 106) in the west-central part of the Circle Cliffs area. In that area, a basal conglomeratic sandstone of the Wingate rests unconformably on the Owl Rock Member of the Chinle. The conglomeratic sandstone is grayish red to pale greenish yellow and crossbedded and contains pebbles of gray chert as much as 1 inch across. The basal contact of the Wingate, below the conglomeratic sandstone, bevels across the "Owl Rock Member disconformably, cutting out as much as 5 feet of beds in 15 feet along contact" (Davidson, 1967, p. 106). These conglomeratic sandstone beds, which are assigned to the Wingate Sandstone, may be equivalents of the Hite Bed.

The contact between the Hite Bed and the massive Wingate Sandstone at many places in southeastern Utah is sharp and conspicuous and, according to J. H. Stewart and R. A. Cadigan (oral commun., 1968), it may be disconformable. It seems apparent that a contact between fluviatile deposits (Hite Bed) and eolian deposits (Wingate Sandstone) should be sharp, for it marks an abrupt change in bedding structures which reflects an abrupt change in environment of deposition. As noted, however, some geologists describe the contact, at least locally in central southeastern Utah, as gradational or intertonguing; the locally sharp contact does not necessarily record a significant hiatus. In addition, the stratigraphic relations to the south indicate that the Hite Bed and the Wingate Sandstone are contemporaneous in part. In northeastern Arizona and in extreme southeastern Utah, the Hite Bed grades into division $A$, which, in turn, intertongues extensively with the Lukachukai Member of the Wingate Sandstone.

Where the Hite Bed is not present in southeastern Utah, the massive Wingate Sandstone overlies the reddish-orange siltstone member (Church Rock Member 
as used by Stewart) of the Chinle Formation. The contact between the formations represents a hiatus that involves a considerable time lapse.

In southeastern Utah the contact between the Chinle Formation and Wingate Sandstone has been variously interpreted as indicated by the quotation below:

"The contact between the Wingate and the underlying Chinle is unconformable and quite sharp over most of the mapped area, though in part it appears conformable." (Smith and others, 1963, p. 23) ; "A widespread unconformity separates the Wingate sandstone from the Chinle formation ***" (Gilluly, 1929, p. 94); "There is a marked unconformity at the top of the Chinle in the San Rafael Swell" and this unconformity is shown extending from the San Rafael Swell to the junction of the Dolores and Colorado Rivers (Gilluly and Reeside, 1928, p. 68, and pl. 15) ; "At the top of the Chinle is an erosional unconformity, $* * * "$ (Hunt and Miller in Hunt and others, 1953, p. 56); "The writer regards the Wingate-Chinle contact as marking a widespread rather abrupt change in conditions of sedimentation, of almost identical nature everywhere but not necessarily contemporaneous." (Dane, 1935, p. 74); "The writer believes that the Wingate is essentially conformable on the Chinle with a zone of lithologic transition between them." (McKnight, 1940, p. 75); "The bedded sandstone indicates continuous deposition and a gradual change from the conditions under which the Chinle sediments accumulated to those under which the Wingate sediments accumulated." (Baker, 1933, p. 41) ; "The writer believes the contact is conformable." (Baker, 1946; p. 63) ; "The contact between $* * *$ the Chinle and the overlying Wingate is arbitrarily selected $* * *$ " (Witkind, 1964, p. 16) ; "The contact between the Chinle and Wingate has a local relief of a few inches except where the formations intertongue." (Thaden and others, 1964, p. 69).

An examination of the various reports suggests that the discrepancies may be due to an attempt to include all fluvial-bedded sandstone deposits in the Chinle Formation and, conversely, to include in the Wingate only massive crossbedded sandstone. The relationship in the Green River Desert area of Utah was described by Baker (1946, p. 62), who stated,

The contact with the overlying Wingate is sharp and marks an abrupt change in lithology at most places in the area, but at other places there is a gradation from typical Chinle lithology through a series of irregularly bedded sandstones into the massive Wingate sandstone, and the contact is placed more or less arbitrarily at the top of the bedded sandstone.

Similarly in the Elk Ridge area (see Lewis and Campbell, 1965, p. B19, columnar section, pl. 1) and in the Clay Hills area (Mullens, 1960, p. 288, 290), fluvial- bedded sandstones are present at the top of the Chinle Formation. In the Elk Ridge area the fluvial-bedded sandstones intertongue with the massive Wingate Sandstone and the contact is therefore conformable (Lewis and Campbell, 1965, p. B19). In the Clay Hills area the conformable contact between the bedded sandstones at the top of the Chinle and the Wingate is shown by the "even character of the contact and the close resemblance in texture and composition of uppermost beds of the Chinle to Wingate Sandstone" (Mullens, 1960, p. 290).

The fluvial-bedded sandstones at the top of the Chinle Formation in the Clay Hills and Elk Ridge areas are now known to be the Hite Bed. The bedded sandstones in the Green River Desert area, which were described by Baker (1946), are also probably the Hite Bed or equivalents of it. The author would place the contact between the Glen Canyon Group and the Chinle Formation at the channeling erosion surface at the base of the bedded sandstones or the Hite Bed.

In the Green River Desert area of Utah, a sharp contact was also described by Baker (1946, p. 62), who stated, "Where the contact is sharp the top of the Chinle shows slight relief, and streaks of grit and chunks of shale and sandstone are occasionally present in the base of the Wingate." The author believes that the Hite Bed is absent from areas where Baker described a sharp contact and that in those areas massive Wingate Sandstone lies on the reddish-orange siltstone member.

In summary, the regional relations in southeastern Utah and adjacent areas strongly suggest that a widespread unconformity separates the Chinle Formation from the Glen Canyon Group. Discrepancies in picking the contact are mostly in the areas where the Hite Bed is present and variously assigned to the overlying or underlying sequence. In view of the different interpretations of the Chinle-Wingate contact in southeastern Utah, however, it is apparent that more detailed work needs to be done in this area before the contact relations can be clarified.

\section{PALEOGEOGRAPHY}

The Chinle Formation accumulated in a large irregularly shaped basin whose axis lay somewhere east of Gallup. The Chinle is about 1,600 feet thick in the Fort Wingate area about 12 miles east of Gallup (Callahan and Cushman, 1955, p. 4). On a summary isopach map of Triassic rocks (McKee and others, 1959, pl. 4), a control point about 50 miles east of Gallup shows 1,820 feet for an interval that includes the Wingate Sandstone and the Chinle Formation. The unit assigned to the Wingate is about 50-80 feet thick in that area; the total Chinle is, therefore, more than 1,700 feet thick. In this area the upper part of the Chinle has been removed 
by erosion, and the total original thickness of the Chinle Formation may have been as much as 2,000 feet.

From this area, the Chinle thins northward to about 1,200 feet in the vicinity of Chinle Valley and to about 400 feet near Moab, Utah. Much of this decrease in thickness results from the northward thinning of the Petrified Forest and older members. (See fig. 6.) The Petrified Forest and older members were probably derived for the most part from a volcanic source (Schultz, 1963, p. C37-C39). Hayes, Simons, and Raup (1965) outlined a Triassic volcanic terrane in southern Arizona that is probably this source area. According to R. A. Cadigan (oral commun., 1967), the poor internal sorting and lack of alteration of the contained tuffaceous material indicate rapid deposition of the Petrified Forest and older members in a sinking basin.

After deposition of the Petrified Forest Member, rates of deposition slowed, and the large basin was filled by the Owl Rock Member and laterally equivalent reddish-orange siltstone member. The illitic reddish-orange siltstone member in southeastern Utah was derived from a source area to the east. In the San Rafael Swell area of Utah, stream directions in the reddish-orange siltstone member are west and northwest (Stewart and others, 1959 , p. 519-520). These directions suggest that a slight divide separated west-flowing streams from the main Chinle basin to the south. Interfingering relations of the illitic reddish-orange siltstone member, however, and the dominantly montmorillonitic content of the Owl Rock Member indicate that from time to time some streams from the eastern source were diverted south into the main basin.

In northeastern Arizona and adjacent areas the Owl Rock Member was deposited in alternating flood-plain and lacustrine environments. During periods of slow deposition, lakes were formed in which limestone was deposited. Some individual limestone beds have been traced in outcrops for 20 miles (Akers and others, 1962, p. B5). At least one limestone bed has been traced for 40 miles (M. E. Cooley, oral commun., 1967) ; these distances indicate rather extensive lakes. Montmorillonitic clay suggests a southern volcanic source area for much of the Owl Rock Member. In southeastern Utah the increasingly illitic composition of the Owl Rock Member in areas where it grades northward into the reddish-orange siltstone member (Church Rock Member as used by Stewart) indicates commingling of sediments from different source areas.

Apparently, widespread erosion and nondeposition began at the end of Owl Rock time; this indicates a period of tectonic adjustment and uplift in southeastern Utah. Uplift is indicated in Utah by a disconformity at the top of the reddish-orange siltstone member of this report (Church Rock Member as used by Stewart). As described by Stewart, Williams, Albee, and Raup $(1959$, p. 523) : "The disconformity at the top of the Chinle formation in most of southeastern Utah probably represents a period of erosion of varying intensity in different areas that resulted from slight upwarping of the region of Chinle deposition."

After this period of uplift and erosion, a shallow new basin developed in northeastern Arizona, partly surrounded by land to the east, north, and west. This shallow depression, the Rock Point basin, widened toward central Arizona; the most rapidly sinking part was in northern Arizona and was occupied by the postulated Rock Point Lagoon (Harshbarger and others, 1957 , p. 23-24; fig. 8, this report). The center of the Rock Point Lagoon was west of the axis of deposition of previously deposited Triassic units and moreover, as has been pointed out by Harshbarger, Repenning, and Irwin (1957, p. 23), younger units of the Glen Canyon Group were deposited in basins whose axes shifted progressively westward. As a result, the Navajo Sandstone, the youngest unit of the Glen Canyon Group, was deposited in a basin whose axis lay far to the west in southwestern Utah. Each of these successive basins of deposition controlled the distribution and thickness of the contained and genetically related units. Thus, division $\mathbf{A}$ is restricted mainly to northeastern Arizona.

The location of the Rock Point basin in northeastern Arizona is strikingly emphasized by indicators of stream directions in the Chinle Formation and in the Hite Bed. Studies of sedimentary structural features in southeasttern Utah show an average resultant dip direction of cross-strata for beds in the reddish-orange siltstone member (Church Rock Member as used by Stewart) of N. $45^{\circ} \mathrm{W}$. for one study and N. $85^{\circ} \mathrm{W}$. for another (Stewart and others, 1959, p. 519). The Hite Bed, however, shows an average resultant dip direction of N. $60^{\circ}$ E. (Stewart and others, 1959, p. 519-520). The near reversal in average stream directions can be explained by an uplift to the west during deposition of the Hite Bed.

Northeast direction of transport of sediment in the Hite Bed in the Hite, Utah, area trends away from the Rock Point basin of northeastern Arizona. The stream directions may indicate a separate basin in southeastern Utah, or the directions may have been measured on tributaries to a master stream draining south into the Rock Point basin. Along Comb Ridge and near Moses Rock, as mentioned, foreset beds in the Hite Bed dip south into the Rock Point basin.

The configuration of the basin that was formed at the end of Chinle time is shown by the fact that away from the axis of the Rock Point basin progressively younger 


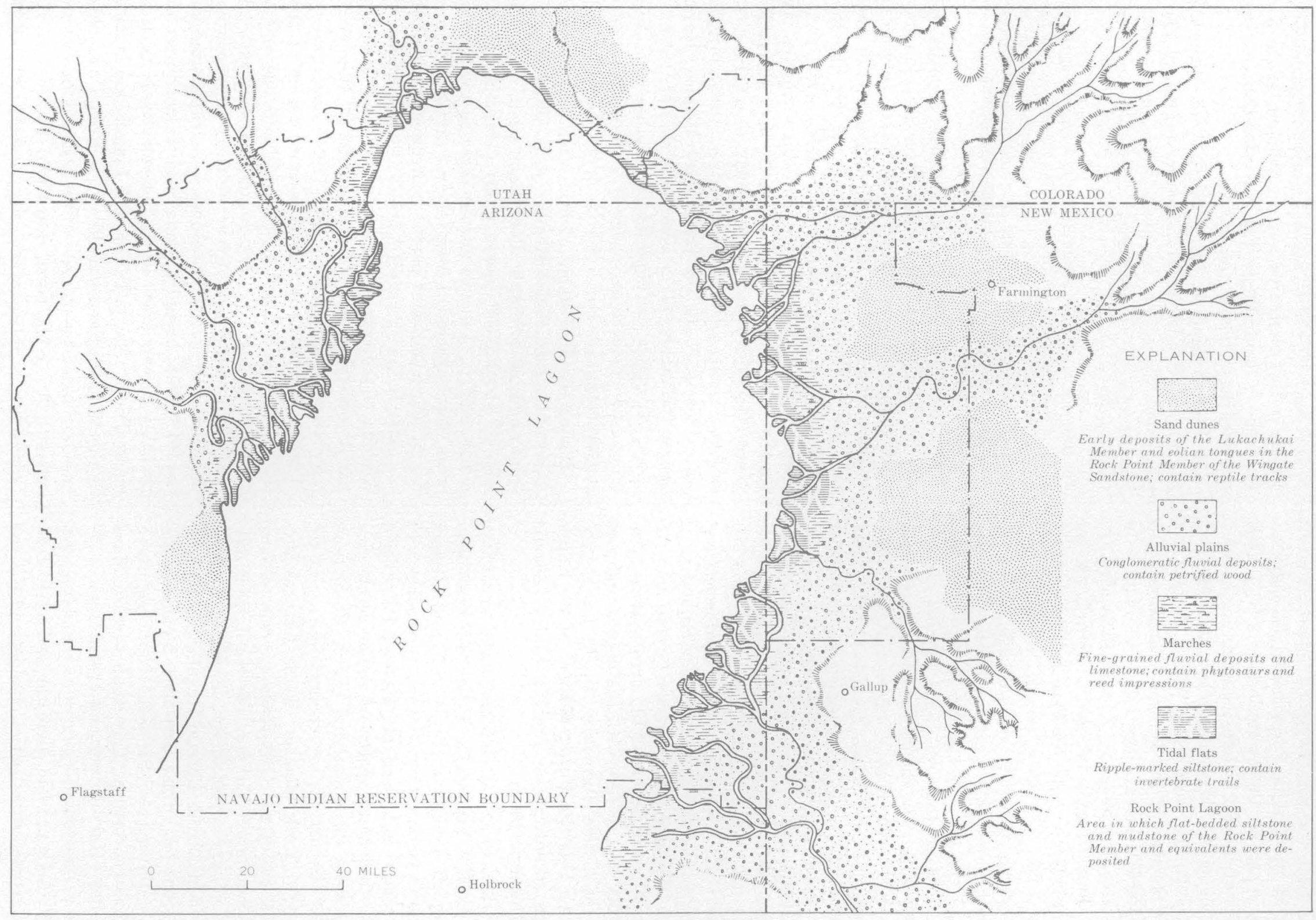

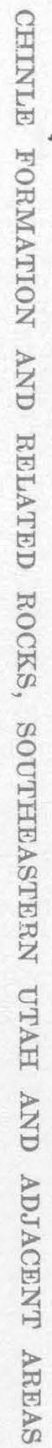

F1GURE 8.-Paleogeographic map of northeastern Arizona and adjacent areas. Map (from Harshbarger and others, 1957, fig. 18) shows hypothetical physiography of area during late stages of deposition of Rock Point Member of Wingate Sandstone. 
units of the Glen Canyon Group lie on progressively older units of the Chinle Formation. (See maps accompanying report by Cooley and others, 1964.) Thus, near the axis of the Rock Point basin in northeastern Arizona, division A rests on the Owl Rock Member. (See fig. 7.) To the west, along Ward Terrace, the Lukachukai Member of the Wingate Sandstone rests on the Owl Rock Member. Along Echo Cliffs and in the Lees Ferry area, the Moenave Formation overlies the Owl Rock. Farther west in southwestern Utah, the Moenave Formation overlies the Petrified Forest Member (Wilson 1965).

East of the axis of the Rock Point basin, the stratigraphic relations are somewhat similar to those west of the axis. Along the Arizona-New Mexico State line, division $\mathrm{A}$ rests on the Owl Rock Member. To the east, the rocks dip below the surface but reappear east of Gallup, and in the Fort Wingate area the Lukachukai Member of the Wingate Sandstone (Harshbarger and others, 1957, p. 10) overlies the Owl Rock Member. Farther east, between Thoreau and Laguna, the Owl Rock Member is beveled out by the unconformity at the top of the Chinle Formation. The Moenave Formation is not present in New Mexico. Either it was not deposited that far east, or it was eroded beneath an unconformity at the base of the Entrada Sandstone of Jurassic age. Farther east, between Grants and Laguna, the pre-Entrada unconformity bevels out the Wingate Sandstone and merges with the unconformity at the top of the Chinle Formation. In the Laguna, N. Mex., area the Petrified Forest Member of the Chinle Formation is unconformably overlain by the Entrada Sandstone (Moench, 1964b).

The formation of the Rock Point basin must have been rapid. Erosion exposed the Petrified Forest Member on the uplifted edges of the basin in southwestern Utah and northwestern New Mexico. In northeastern Arizona, streams that drained into the Rock Point basin laid down a thin basal veneer of conglomerate that was derived from the underlying Chinle Formation; these streams also cut shallow channels on top of the underlying Owl Rock Member. These features suggest that the top of the Owl Rock was subjected to subaerial erosion in much of northeastern Arizona during the preliminary stages of the development of the Rock Point basin. In the Carrizo Mountains area, however, a limestone bed of the Owl Rock Member intertongues with division A (Strobell, 1956), and there, deposition was continuous. This small area of about 24 square miles (Harshbarger and others, 1957, p. 7) where the units intertongue represents a possibly deeper part of the Rock Point basin. Here, the Owl Rock Member was not exposed to subaerial erosion, and the end of Owl Rock deposition was not so abrupt as it was elsewhere. In this small area, a small remnant lake or pond lingered on during the period of erosion that elsewhere preceded deposition of division $\mathbf{A}$.

Most of division A, or the Rock Point Member of the Wingate Sandstone (Harshbarger and others, 1957), represents deposition in quiet water. However, as pointed out by Harshbarger, Repenning, and Irwin $(1957$, p. 23) :

The presence of a few lenses of fluviatile sandstone at the base of the Rock Point suggests that streams flowed into the basin during the initial stages of deposition. However, initial deposition of this type was of short duration throughout most of the area, and typical silty flatbedded quiet-water sediments soon covered the basal beds.

At several places, marginal fluviatile deposits were laid down by streams that entered the Rock Point Lagoon (fig. 8). The most extensive fluvial deposits are on the southeast margin of the Rock Point basin where they are found throughout division $\mathbf{A}$ (or the Rock Point Member, Harshbarger and others, 1957, p. 23). Similarly, fluvial deposits are present along the Arizona-New Mexico State line and in the area west of $\mathrm{Ka}$ yenta (Harshbarger and others, 1957, pl. 2). In northeastern Arizona such fluvial deposits have been included with division A (or the Rock Point Member, Harshbarger and others, 1957, p. 23). The similar, but more extensive, fluviatile deposits in southeastern Utah around the northern periphery of the Rock Point basin constitute the Hite Bed.

During the final stages of deposition of division A, dunes of the Lukachukai Member of the Wingate Sandstone migrated across the Rock Point basin. In a large area of about 6,000 square miles (Harshbarger and others, 1957, p. 7) in northeastern Arizona and adjacent areas, the Lukachukai Member and division A interfinger, which indicates partial contemporaneity of the two units. In the Carrizo Mountains area of northeastern Arizona, the intertonguing between division $\mathrm{A}$ and the partly overlying and partly equivalent Wingate is especially pronounced. Strobell (1956) described the Wingate Sandstone in this area as consisting of "two thick lithologic units $* * *$ a lower siltstone and an upper sandstone $* * *$ which could be mapped separately only on the basis of very arbitrary and sometimes inconsistent division." The dunes were transported into the Rock Point basin by winds from the northwest and probably accumulated in an interior-desert environment (Poole, 1962, p. D148). The Lukachukai Member of the Wingate Sandstone filled the Rock Point basin and overlapped the margins of the basin to the east and extended far to the north into Utah. To the west, the Lukachukai Member extends only a short distance be- 
yond the limits of division A (Harshbarger and others, 1957, pl. 2). The westward extent of the Lukachukai Member was apparently controlled by the configuration of the Rock Point basin.

Toward the end of the deposition of the Lukachukai Member of the Wingate Sandstone, the Moenave Formation began to accumulate. The axis of the Moenave basin of deposition shifted to the west of the Rock Point basin. There was, however, no halt in sedimentation, for the Lukachukai Member of the Wingate and the Moenave Formation intertongue in the Ward Terrace area (Harshbarger and others, 1957, p. 23 and pl. 2). Detailed descriptions of the Moenave Formation, as well as of the younger and older units of the Glen Canyon Group, are in the report by Harshbarger, Repenning, and Irwin (1957).

\section{CONCLUSIONS}

Divisions A, originally assigned to the Chinle Formation by Gregory (1917), can be recognized in a limited area of northeastern Arizona and southeastern Utah. Division A however, has been given two names and has been assigned to two different formations by subsequent workers. It seems appropriate to retain the name Rock Point Member of the Wingate Sandstone for division A.

The name Church Rock Member of the Chinle Formation has been used for division $A$ and for the Hite Bed in the Monument Valley area. The Hite Bed has a much wider distribution than rocks more typical of division $\mathrm{A}$ and should be recognized separately. The name Church Rock, moreover, has been applied to units of different ages in different places. In southeastern Utah the name has been applied to the reddish-orange siltstone member of this report (Church Rock Member as used by Stewart) that is now known to be older than division $\mathbf{A}$. In the author's opinion the reddish-orange siltstone member of most of southeastern Utah should be considered a facies of the Owl Rock Member or should be renamed.

\section{REFERENCES CITED}

Akers, J. P., Cooley, M. E., and Repenning, C. A., 1958. Moenkopi and Chinle formations of Black Mesa [Ariz.] and adjacent areas, in New Mexico Geol. Soc. Guidebook of the Black Mesa basin, northeastern Arizona, 9th Field Conf., Oct. 1958: p. 88-94.

Akers, J. P., McClymonds, N. E., and Harshbarger, J. W., 1962, Geology and ground water of the Red Lake area, Navajo Indian Reservation, Arizona and New Mexico: U.S. Geol. Survey Water-Supply Paper 1576-B, p. B1-B12.

Baker, A. A., 1933, Geology and oil possibilities of the Moab district, Grand and San Juan Counties, Utah: U.S. Geol. Survey Bull. 841, $95 \mathrm{p}$.

1946, Geology of the Green River Desert-Cataract Canyon region, Emery, Wayne, and Garfield Counties, Utah: U.S. Geol. Survey Bull. 951, 122 p. [1947].
Beaumont, E. C., and Dixon, G. H., 1965, Geology of the Kayenta and Chilchinbito quadrangles, Navajo County, Arizona : U.S. Geol. Survey Bull. 1202-A, p. A1-A28.

Cadigan, R. A., 1961, Geologic interpretation of grain-size distribution measurements of Colorado Plateau sedimentary rocks: Jour. Geology, v. 69, no. 2, p. 121-142.

Callahan, J. T., 1951, The geology of the Glen Canyon Group along the Echo Cliffs, Arizona : Plateau, v. 23, no. 4, p. 49-57.

Callahan, J. T., and Cushman, R. L., 1955, Geology and groundwater supplies of the Fort Wingate Indian school area, McKinley County, New Mexico: U.S. Geol. Survey Circ. $360,12 \mathrm{p}$.

Camp, C. L., 1930, A study of the phytosaurs with description of new material from western North America: California Univ. Mem., v. 10, $174 \mathrm{p}$.

Cooley, M. E., 1959, Triassic stratigraphy in the state line region of west-central New Mexico and east-central Arizona, in New Mexico Geol. Soc. Guidebook of west-central New Mexico, 10th Field Conf., Oct. 1959: p. 66-73.

Cooley, M. E., Harshbarger, J. W., Akers, J. P., and Hardt, W. F-, 1964, Regional hydrogeology of the Navajo and Hopi Indian Reservations, Arizona, New Mexico, and Utah, with a section on Vegetation, by O. N. Hicks: U.S. Geol. Survey openfile report, $245 \mathrm{p}$.

Dane, C. H., 1935, Geology of the Salt Valley anticline and adjacent areas, Grand County, Utah: U.S. Geol. Survey Bull. 863, 184 p. [1936].

Dane, C. H., and Bachman, G. O., 1957, Preliminary geologic map of the northwestern part of New Mexico: U.S. Geol. Survey Misc. Geol. Inv. Map I-224.

Davidson, E. S., 1967, Geology of the Circle Cliffs area, Garfield and Kane Counties, Utah: U.S. Geol. Survey Bull. 1229, $140 \mathrm{p}$.

Gilluly, James, 1929, Geology and oil and gas prospects of part of the San Rafael Swell, U.tah: U.S. Geol. Survey Bull. 806-C, p. 69-130.

Gilluly, James, and Reeside, J. B., Jr., 1928, Sedimentary rocks of the San Rafael Swell and some adjacent areas in eastern Utah: U.S. Geol. Survey Prof. Paper 150-D, p. 61-110.

Gregory, H. E., 1917, Geology of the Navajo country-a reconnaissance of parts of Arizona, New Mexico, and Utah: U.S. Geol. Survey Prof. Paper 98, 161 p.

1950, Geology and geography of the Zion Park region, Utah and Arizona: U.S. Geol. Survey Prof. Paper 220, 200 p. [1952].

Harshbarger, J. W., Repenning, C. A., and Irwin, J. H., 1957, Stratigraphy of the uppermost Triassic and the Jurassic rocks of the Navajo country: U.S. Geol. Survey Prof. Paper $291,74 \mathrm{p}$.

Hayes, P. T., Simons, F. S., and Raup, R. B., 1965, Lower Mesozoic extrusive rocks in southeastern Arizona-the Canelo Hills Volcanics : U.S. Geol. Survey Bull. 1194-M, p. M1-M9.

Hunt, C. B., assisted by Averitt, Paul, and Miller, R. L., 1953, Geology and geography of the Henry Mountain region, Utah : U.S. Geol. Survey Prof. Paper 228, 234 p. [1954].

Lewis, R. Q., Sr.; 'and Campbell, R. H., 1965, Geology and uranium deposits of Elk Ridge and vicinity, San Juan County, Utah : U.S. Geol. Survey Prof. Paper 474-B, p. B1-B69.

McKee, E. D., Oriel, S. \$., Ketner, K. B., MacLachlan, M. E., Goldsmith, J. W., MacLachlan, J. C., and Mudge, M. R., 1959, Paleotectonic maps of the Triassic system : U.S. Geol. Survey Misc. Geol. Inv. Map I-300, $33 \mathrm{p}$. 
McKnight, E. T., 1940, Geology of area between Green and Colorado Rivers, Grand and San Juan Counties, Utah: U.S. Geol. Survey Bull. 908, 147 p. [1941].

Moench, R. H., 1964a, Geology of the Dough Mountain quadrangle, New Mexico: U.S. Geol. Survey Geol. Quad. Map GQ-354.

1964b, Geology of the South Butte quadrangle, Valencia County, New Mexico: U.S. Geol. Survey Geol. Quad. Map GQ-355.

Mullens, T. E., 1960, Geology of the Clay Hills area, San Juan County, Utah: U.S. Geol. Survey Bull. 1087-H, p. 259-336.

O'Sullivan, R. B., 1965, Geology of the Cedar Mesa-Boundary Butte area, San Juan County, Utah : U.S. Geol. Survey Bull. 1186, $128 \mathrm{p}$.

Petersen, R. G., 1959, Preliminary geologic map of the Emmett Wash NE quadrangle, Coconino County, Arizona : U.S. Geol. Survey Mineral Inv. Map MF-215.

1961, Preliminary geologic map of the [Paria Platea SE] quadrangle, Coconino County, Arizona: U.S. Geol. Survey Mineral Inv. Map MF-196.

Petersen, R. G., and Wells, J. D., 1960, Preliminary geologic map of the Emmett Wash NW quadrangle, Coconino County, Arizona: U.S. Geol. Survey Mineral Inv. Map MF-197 [1961].

Phoenix, D. A., 1963, Geology of the Lees Ferry area, Coconino County, Arizona: U.S. Geol. Survey Bull. 1137, 86 p.

Poole, F. G., 1962, Wind directions in late Paleozoic to middle Mesozoic time on the Colorado Plateau, in Short papers in geology, hydrology, and topography : U.S. Geol. Survey Prof. Paper 450-D, p. D147-D151.

Repenning, C. A., Cooley, M. E., and Akers, J. P., 1965. Stratigraphy of the Chinle and Moenkopi Formations, Navajo and Hopi Indian Reservations, Arizona, New Mexico, and Utah : U.S. Geol. Survey open-file report, $146 \mathrm{p}$.

Schultz, L. G., 1963, Clay minerals in Triassic rocks of the Colorado Plateau: U.S. Geol. Survey Bull. 1147-C, p. C1O71.

Smith, C. T., 1954, Geology of the Thoreau quadrangle, McKinley and Valencia Counties, New Mexico: New Mexico Bur. Mines and Mineral Resources Bull. 31, 36 p.
Smith, J. F., Jr., Huff, L. C., Hinrichs, E. N., and Luedke, R. G., 1963, Geology of the Capitol Reef area, Wayne and Garfield Counties, Utah: U.S. Geol. Survey Prof. Paper 363, 102 p.

Stewart, J. H., 1957, Proposed nomenclature of part of Upper Triassic strata in southeastern Utah : Am. Assoc. Petroleum Geologists Bull., v. 41, no. 3, p. 441-465.

Stewart, J. H., Williams, G. A., Albee, H. F., and Raup, O. B., 1959, Stratigraphy of Triassic and associated formations in part of the Colorado Plateau region, with a section on Sedimentary petrology, by R. A. Cadigan: U.S. Geol. Survey Bull. 1046-Q, p. 487-576.

Strobell, J. D., Jr., 1956, Geology of the Carrizo Mountains area in northeastern Arizona and northwestern New Mexico: U.S. Geol. Survey Oil and Gas Inv. Map OM-160.

Thaden, R. E., Trites, A. F., Jr., and Finnell, T. L., 1964, Geology and ore deposits of the White Canyon area, San Juan and Garfield Counties, Utah: U.S. Geol. Survey Bull. 1125, $166 \mathrm{p} .[1965]$.

Wells, J. D., 1960, Stratigraphy and structure of the House Rock Valley area, Coconino County, Arizona: U.S. Geol. Survey Bull. 1081-D, p. 117-158 [1961].

Wilson, R. F., 1965, Triassic and Jurassic strata of southwestern Utah, in Guidebook to the geology of Utah, no. 19, Geology and resources of south-central Utah: Utah Geol. Soc. and Intermtn. Assoc. Petroleum Geologists, p. 31-46.

Wilson, R. F., and Stewart, J. H., 1967, Correlation of Upper Triassic and Triassic (?) Formations between southwestern Utah and southern Nevada : U.S. Geol. Survey Bull. 1244-D, p. D1-D20.

Witkind, I. J., 1964, Geology of the Abajo Mountains area, San Juan County, Utah: U.S. Geol. Survey Prof. Paper 453, $110 \mathrm{p}$.

Witkind, I. J., and Thaden, R. E., 1963, Geology and uraniumvanadium deposits of the Monument Valley area, Apache and Navajo Counties, Arizona, with sections on Serpentine at Garnet Ridge, by H. E. Malde and R. E. Thaden, and Mineralogy and paragenesis of the ore deposit at the Monument No. 2 and Cato Sells mines, by D. H. Johnson: U.S. Geol. Survey Bull. 1103, 171 p. 